\title{
Cataloguing and Selection of mRNAs Localized to Dendrites in Neurons and Regulated by RNA-Binding Proteins in RNA Granules
}

\author{
Rie Ohashi $1, *(\mathbb{D})$ and Nobuyuki Shiina $2,3,4, *$ (D) \\ 1 Life Science Research Center, University of Toyama, Toyama 930-0194, Japan \\ 2 Laboratory of Neuronal Cell Biology, National Institute for Basic Biology, Okazaki, Aichi 444-8585, Japan \\ 3 Department of Basic Biology, SOKENDAI, Okazaki, Aichi 444-8585, Japan \\ 4 Exploratory Research Center on Life and Living Systems, Okazaki, Aichi 444-8585, Japan \\ * Correspondence: ohashi@cts.u-toyama.ac.jp (R.O.); nshiina@nibb.ac.jp (N.S.); \\ Tel.: +81-76-434-7171 (R.O.); Tel.: +81-564-55-7620 (N.S.)
}

Received: 16 December 2019; Accepted: 20 January 2020; Published: 22 January 2020

\begin{abstract}
Spatiotemporal translational regulation plays a key role in determining cell fate and function. Specifically, in neurons, local translation in dendrites is essential for synaptic plasticity and long-term memory formation. To achieve local translation, RNA-binding proteins in RNA granules regulate target mRNA stability, localization, and translation. To date, mRNAs localized to dendrites have been identified by comprehensive analyses. In addition, mRNAs associated with and regulated by RNA-binding proteins have been identified using various methods in many studies. However, the results obtained from these numerous studies have not been compiled together. In this review, we have catalogued mRNAs that are localized to dendrites and are associated with and regulated by the RNA-binding proteins fragile X mental retardation protein (FMRP), RNA granule protein 105 (RNG105, also known as Caprin1), Ras-GAP SH3 domain binding protein (G3BP), cytoplasmic polyadenylation element binding protein 1 (CPEB1), and staufen double-stranded RNA binding proteins 1 and 2 (Stau1 and Stau2) in RNA granules. This review provides comprehensive information on dendritic mRNAs, the neuronal functions of mRNA-encoded proteins, the association of dendritic mRNAs with RNA-binding proteins in RNA granules, and the effects of RNA-binding proteins on mRNA regulation. These findings provide insights into the mechanistic basis of protein-synthesis-dependent synaptic plasticity and memory formation and contribute to future efforts to understand the physiological implications of local regulation of dendritic mRNAs in neurons.
\end{abstract}

Keywords: local translation; dendritic mRNA; RNA-binding proteins; RNA granules

\section{Introduction}

Spatiotemporal translational regulation is key to increasing the concentration of specific proteins to exert their functions at specific timings and locations in cells. In neurons, mRNAs are translated not only in the cell soma but also in axons and dendrites [1,2]. Local translation in axons is mainly required for axon outgrowth and maintenance, and local translation in dendrites is necessary for synaptic plasticity and long-term memory formation [1-4].

In 1996, Kang and Schuman revealed that long-term potentiation (LTP) occurs in the stratum radiatum (SR), which is a dendrite-enriched region in hippocampal CA1, even after the SR was isolated from the cell-soma-enriched stratum pyramidale (SP). LTP in the isolated SR was lost after inhibition of protein synthesis [5]. Their findings suggest the existence of "local translation" in neurites, and that proteins translated locally in neurites are sufficient for LTP induction. Since these findings, our understanding of local translation in dendrites has deepened substantially: specific mRNAs are 
recruited to "RNA granules", which are membrane-less RNA-protein complexes containing mRNAs, RNA-binding proteins, ribosomes, and translational regulators, and are transported to dendrites using microtubules as rails [6-8]. RNA-binding proteins in RNA granules are key regulators of mRNA localization and protein synthesis. Dysfunction of these proteins causes abnormalities in dendritic mRNA localization and translation, resulting in impairment of higher-order brain functions, such as neurodevelopmental disorders, intellectual and mental disorders, and loss of long-term memory formation $[9,10]$.

This review catalogues and selects mRNAs that are localized to dendrites and regulated by RNA-binding proteins in RNA granules. Here, we focus on dendritic mRNAs that have been identified in common in several studies that identified dendritic mRNAs based on various criteria using comprehensive RNA sequencing (RNA-seq) of the SR from rodent hippocampal CA1. These mRNAs are further classified into groups according to the functions of the mRNA-encoded proteins. In addition, we focus on the major RNA-binding proteins in RNA granules and list their target mRNAs and effects on mRNAs. Furthermore, we compared our selected set of dendritic mRNAs with the RNA-binding protein target mRNAs and discuss the contribution of RNA-binding proteins to mRNA regulation, such as mRNA expression, stability, localization, and translation, for the regulation of local translation in dendrites.

\section{2. mRNAs That Are Localized in the Dendrite-Enriched Layer of the Hippocampus}

In the 1990s, several mRNAs were identified as dendritically localized mRNAs, among which Camk2a, Map2, Arc, and Insp3r1 mRNAs were intensively studied [11,12]. Later, with the help of advances in deep sequencing technology, thousands of mRNAs that are localized to dendrites have been identified from the dendrite-enriched layer (SR) in the rodent hippocampus [13-17]. We briefly review studies that comprehensively identified the candidates of dendritic mRNAs from the SR of hippocampal CA1 using RNA-seq (Figure 1) and focus on selective mRNAs identified in common among these studies.

\section{1. $m R N A$ s That Are Identified in SR Isolated from Rodent Hippocampal CA1}

Cajigas et al. identified mRNAs that are abundant in the synaptic neuropil in the rat hippocampus (Figure 1) [15]. They microdissected the SR and stratum lacunosum moleculare (SLM) as the neuropil layer from the hippocampal CA1 region of adult rat brains and subjected them to RNA-seq. From the raw dataset of RNA-seq, they subtracted mRNAs enriched in various types of cells other than pyramidal neurons, such as glial cells, interneurons, blood vessels, nuclei, and mitochondria, and identified 2550 transcripts as dendritic and/or axonal mRNAs. Subsequent mRNA labeling with high-resolution in situ hybridization revealed that all 71 mRNAs for which the authors developed probes were detected in dendrites, suggesting that most of the mRNAs identified from the SR and SLM layers using this method are dendritic mRNAs.

Nakayama et al. identified mRNAs more enriched in the SR layer compared with the SP layer in the hippocampus of adult mice (Figure 1) [16]. They microdissected and isolated the SP and SR layers from mouse hippocampal CA1 and subjected them to RNA-seq. From the RNA-seq raw data, as in the study of Cajigas et al., mRNAs enriched in various cell types other than pyramidal neurons were subtracted. Relative read counts of transcripts in the SR compared with the SP were calculated, which identified 2106 SP-enriched mRNAs and 1122 SR-enriched mRNAs as somatically and dendritically enriched mRNAs, respectively. The authors also revealed that the enrichment of SR-enriched mRNAs in the SR layer was reduced by conditional knockout (cKO) of RNA granule protein 105 (RNG105, also known as Caprin1), deficiency of which severely impaired long-term memory formation.

Ainsley et al. identified ribosome-bound mRNAs in the hippocampus of mice that had received a novel experience causing activity-induced memory formation (Figure 1) [17]. They collected tissues from the SP and SR layers of the hippocampal CA1 of adult mice expressing EGFP-tagged ribosomal protein L10a (Rpl10a) specifically in pyramidal neurons but not in glia or interneurons. SP- and 
SR-enriched mRNAs bound to EGFP-tagged ribosomes were obtained by immunoprecipitation and then sequenced using RNA-seq. The RNA-seq data from resting mice and mice exposed to a novel experience consisting of a contextual-fear-conditioning trial were analyzed by machine learning classification, which listed 1860 ribosome-bound dendritically localized mRNAs after fear conditioning. Because mRNA binding to ribosomes increases during translation, these ribosome-bound mRNAs were thought to be translated locally in dendrites in an activity-dependent manner.

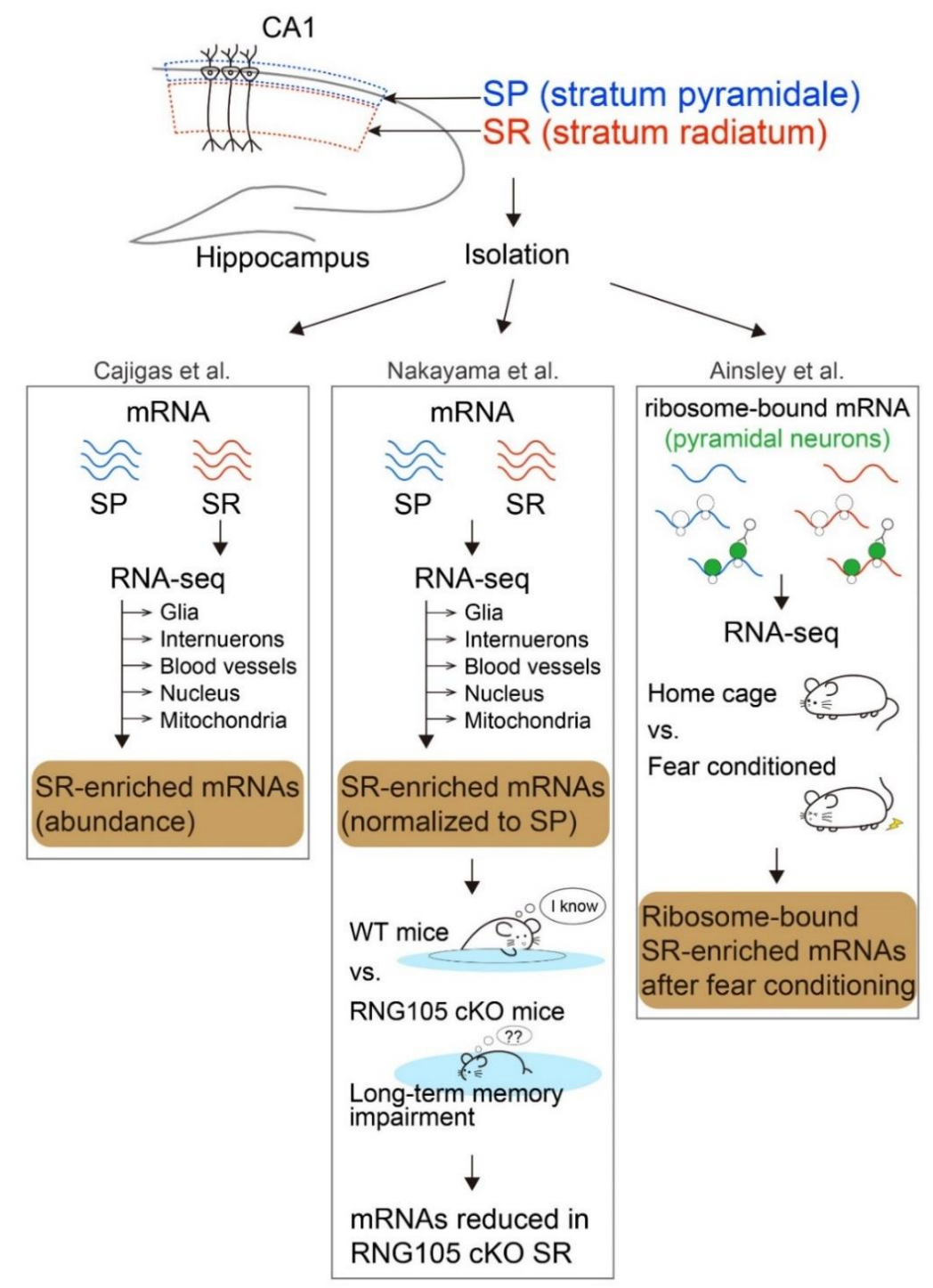

Figure 1. Identification of mRNAs localized to the dendrite-enriched stratum radiatum (SR) layer in hippocampal CA1. Three different groups comprehensively identified mRNAs localized in the hippocampal SR layer using next-generation RNA sequencing. In the hippocampus, somas align in the stratum pyramidale (SP) and dendrites elongate into the SR. Cajigas et al., Nakayama et al., and Ainsley et al. identified mRNAs localized to the hippocampal SP and SR layers after isolating the layers from rodents. Cajigas et al. identified mRNAs abundant in the SR of the rat hippocampal CA1 region. Nakayama et al. identified mRNAs that are more enriched in the SR layer compared with the SP layer in the mouse hippocampus. They also identified mRNAs that were localized to the SR but were reduced in the SR of RNA granule protein 105 (RNG105, also known as Caprin1) conditional knockout (cKO) mice that showed long-term memory impairment. Ainsley et al. identified ribosome-bound mRNAs in the hippocampal SR of fear-conditioned mice. In this review, we compared the SR-enriched mRNA lists from these studies (colored in brown) and focused on dendritic mRNAs identified in common in all of these studies (Supplementary Table S1). 
These three studies used different strategies to identify dendritic mRNAs in term of abundance, relative enrichment, and ribosome binding. In particular, the strategy used by Ainsley et al. differed significantly from the other two studies in that they used transgenic mice overexpressing Rp110a and analyzed selective mRNAs that bound to ribosomes. Due to this difference, it may be supposed that the overlap of dendritic mRNAs between Ainsley et al. and the other two studies may be smaller than that between the other two. However, this was not the case (Figure 2a), suggesting that dendritic translation may not occur in a highly mRNA-selective manner. We found that the number of overlapped dendritic mRNAs among the three studies was 78 , representing only $3 \%-7 \%$ of the total number of dendritic mRNAs identified in each study (Figure 2a, Table 1, and Supplementary Table S1). Therefore, these 78 mRNAs are considered fairly reliable candidates for mRNAs localized to dendrites and locally translated in an activity-dependent manner. Recently, Farris et al. also identified mRNAs localized in the hippocampal subregions (CA1, CA2, CA3, and the dentate gyrus) of the adult mouse hippocampus [18]. They found that 68 of the 78 mRNAs overlapped as mRNAs enriched in the SR layer of the CA1 region among their study and the three studies above [18], supporting the reliable dendritic localization of the commonly identified mRNAs.

The general functions and neuronal/brain functions of these 78 mRNA-encoded proteins are summarized in Supplementary Table S1 [19-194]. Of note, most of the 78 mRNAs encoded proteins involved in the regulation of synaptic functions, such as $\alpha$-amino-3-hydroxy-5-methyl-4isoxazolepropionic acid (AMPA) receptor trafficking and transmission, $N$-methyl-D-aspartate (NMDA) receptor activity, ion channel activity, spine growth and maintenance, synaptic plasticity, LTP, and learning and memory. In addition, their dysfunctions were associated with a variety of neuropsychiatric disorders such as fragile X syndrome, Alzheimer's disease, Down syndrome, schizophrenia, Parkinson's disease, and autism spectrum disorder (ASD) (Supplementary Table S1). In order to understand the major biological and functional categories in which the proteins encoded by these mRNAs are involved, they were classified by gene ontology (GO) enrichment analysis using DAVID 6.8. As a result, these mRNAs were enriched mainly in the categories of "ribosome", "synapse", "elongation factor", "dendritic spine", and "ionotropic glutamate receptor complex" (Figure 2b,c).

Table 1. Summary of Supplementary Tables S1 and S2.

\begin{tabular}{|c|c|c|c|c|}
\hline Table & Title & \multicolumn{3}{|l|}{ Content } \\
\hline $\begin{array}{c}\text { Supplementary } \\
\text { Table S1 }\end{array}$ & $\begin{array}{l}\text { Dendritic } \\
\text { mRNAs and their } \\
\text { associated } \\
\text { RNA-binding } \\
\text { proteins }\end{array}$ & \multicolumn{3}{|c|}{$\begin{array}{l}\text { - Candidate dendritic mRNAs commonly identified in studies that } \\
\text { used RNA sequencing (RNA-seq) (Cajigas et al., 2012; } \\
\text { Ainsley et al., 2014; Nakayama et al., 2017) are listed, and the general } \\
\text { and neuronal functions of the encoded proteins are summarized. } \\
\text { Association of these mRNAs with RNA-binding proteins of RNA } \\
\text { granules-FMRP, RNG105/Caprin1, G3BP, CPEB1, Stau1, and } \\
\text { Stau2-are indicated. }\end{array}$} \\
\hline \multirow[t]{6}{*}{$\begin{array}{l}\text { Supplementary } \\
\text { Table S2a-e }\end{array}$} & \multirow[t]{6}{*}{$\begin{array}{l}\text { Target mRNAs of } \\
\text { RNA-binding } \\
\text { proteins of RNA } \\
\text { granules }\end{array}$} & \multirow[t]{6}{*}{$\begin{array}{l}\text { mRNAs associated with and } \\
\text { regulated by the RNA-binding } \\
\text { proteins of RNA granules are listed. } \\
\text { Effects of the RNA-binding proteins } \\
\text { on the mRNAs are summarized. }\end{array}$} & & RNA-binding proteins \\
\hline & & & $2 a$ & FMRP \\
\hline & & & $2 b$ & RNG105/Caprin1 \\
\hline & & & $2 c$ & G3BP \\
\hline & & & $2 \mathrm{~d}$ & CPEB1 \\
\hline & & & $2 \mathrm{e}$ & Staufen, Stau1, Stau2 \\
\hline
\end{tabular}

1 "Target mRNA (Gene Name)" indicates the gene name shown in the references. "Gene Symbol" indicates the official gene symbol in Mus musculus. ${ }^{2}$ Because the comprehensive analyses identified a large number of target mRNAs, the identified mRNAs are not concretely listed but indicated by asterisks $\left({ }^{*}\right)$. However, some comprehensive studies analyzed particular mRNAs more specifically. In such cases, those particular mRNAs are listed separately. Abbreviations: FMRP_fragile X mental retardation protein; RNG105-RNA granule protein 105; G3BP-Ras-GAP SH3 domain binding protein; CPEB1—cytoplasmic polyadenylation element binding protein 1; Stau1 and Stau2-staufen double-stranded RNA binding proteins 1 and 2. 


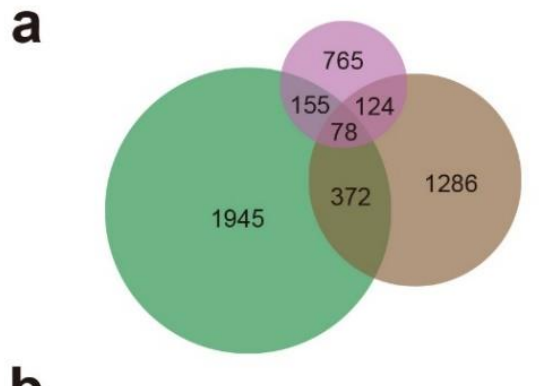

Dendritically enriched mRNAs identified by different criteria

Cajigas et al., 2012

Nakayama et al., 2017

Ainsley et al., 2014

b

Fold enrichment

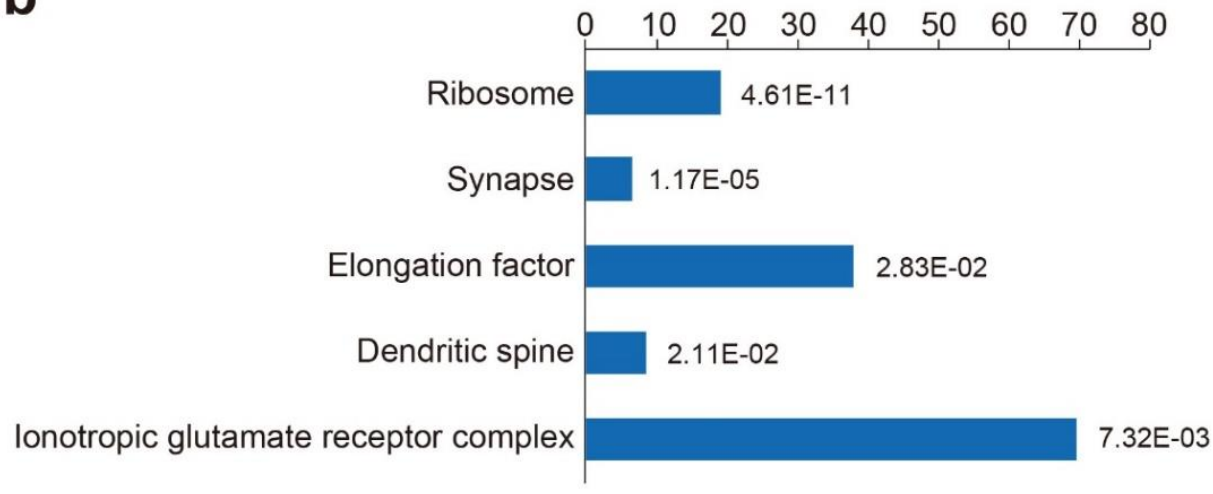

C

mRNA lists in the GO categories

\begin{tabular}{ccccc}
\hline Ribosome & Synapse & $\begin{array}{c}\text { Elongation } \\
\text { factor }\end{array}$ & $\begin{array}{c}\text { Dendritic } \\
\text { spine }\end{array}$ & $\begin{array}{c}\text { Ionotropic } \\
\text { glutamate } \\
\text { receptor } \\
\text { complex }\end{array}$ \\
\hline Rpl21 & Arc & Eef1a1 & Arc & Shank1 \\
Rps2 & Dlgap3 & Eef2 & Dlgap3 & Dlg2 \\
Rplp1 & Kcnab2 & Eef1b2 & Shank1 & Dlg4 \\
Rpl17 & Shank1 & & Sipa1l1 & \\
Rpl4 & Crtc1 & & Dlg4 & \\
Rpl36a & Ncs1 & & & \\
Rpl10 & Dlg2 & & & \\
Rps3a & Homer2 & & & \\
Rps25 & Dlg4 & & & \\
Rps7 & Camk2a & & & \\
Rps16 & Psd3 & & & \\
Rpl31 & Sipa11 & & & \\
Rpl13a & Cdk16 & & & \\
Rps20 & & & & \\
\hline
\end{tabular}

Figure 2. Gene ontology (GO) categories in which the identified dendritic mRNAs were enriched. The three studies (Cajigas et al., 2012; Ainsley et al., 2014; Nakayama et al., 2017) were compared, and 78 mRNAs were found to be commonly identified in the studies (a). The 78 mRNAs were classified by GO enrichment analysis using DAVID 6.8. GO categories in which the mRNAs were significantly enriched (b), and the list of mRNAs included in the GO categories (c) are shown.

\subsection{Unexpected GO Categories of the Catalogued Dendritic mRNAs: "Ribosome" and "Elongation Factor"}

The fact that many mRNAs encoding ribosomal proteins were found in the dendritic mRNAs was surprising. It is well known that ribosome subunits are assembled in the nucleus, where ribosome assembly requires many steps and with the help of various regulatory factors [195]. The resulting ribosomes are recruited to RNA granules and transported to dendrites $[1,7,196]$. Thus, although the possibility of ribosome biogenesis in dendrites cannot be ruled out, it seems almost impossible. 
Another possible involvement of local translation of ribosomal proteins is ribosome heterogeneity in neurons. It has been suggested that the structure of ribosomes is often not uniform in different tissues, in cells at different developmental stages, and even in distinct subcellular locations within the same cell. Such ribosomes recognize specific mRNAs through differences in components and chemical modifications of ribosomal subunit proteins, which is known as the "ribosome filter hypothesis" [197]. For example, the components of ribosomal subunits are different between testis and liver [198], ribosomes in mouse embryonic stem cells are heterogeneous and translate distinct subpools of mRNAs [199], and changes in the composition of ribosomal proteins regulate the translation of specific mRNAs in neocortical development [200,201]. In yeast, translation of ASH mRNA, localized at the tip of daughter cells, requires ribosomes composed of specific ribosomal protein paralogs [202]. Given that mRNA translation differs between soma and dendrites, local translation in dendrites of mRNAs encoding ribosomal proteins could cause subcellular ribosome heterogeneity in neurons. This mechanism may require the exchange of ribosomal subunit proteins in dendrites. Ribosomal protein exchange has been reported in Escherichia coli in several studies [203-205], and notably, damaged ribosomes are repaired by exchanging ribosomal subunit proteins [206]. Thus, the exchange of ribosomal subunit proteins could occur in neurons, which may contribute not only to ribosome heterogeneity but also to the maintenance of functional ribosomes in dendrites. Another possibility is that ribosomal subunit proteins have their own functions by themselves. The physiological relevance of the localization of ribosomal-protein-encoding mRNAs to dendrites is unknown, but it is very interesting whether the dendritic localization is involved in the local regulation of synaptic plasticity and higher-order brain functions.

The GO category "elongation factor" included Eef1a1, Eef1b2, and Eef2 mRNAs. Many translational regulators are known to be recruited to RNA granules as proteins and transported to dendrites $[6,196]$. In contrast, the above elongation factors are recruited as mRNAs and may be translated locally in dendrites. It is interesting that, among several steps of translation such as initiation, elongation, and termination, the factors involved in the elongation step were selectively enriched in dendritic mRNAs. Translation initiation steps are mainly regulated by phosphorylation and dephosphorylation of the initiation factors. For example, phosphorylation of eIF4E promotes the initiation step, whereas phosphorylation of eIF $2 \alpha$ in stress conditions inhibits translation initiation. In contrast, in the elongation step, the exchange between GTP and GDP forms of eEF1a and eEF2 is a key regulatory mechanism [207]. In addition, control of the amount of elongation factors may be important for the regulation of elongation. This may be related to the fact that decreased expression levels of Eef1a1 and Eef1b2 are associated with Alzheimer's disease and intellectual disability, respectively [67,69]. Increasing concentrations of elongation factors at specific timings and locations mediated by local translation could be important for local synaptic regulation.

\subsection{Expected GO Categories of the Catalogued Dendritic mRNAs: "Synapse", "Dendritic Spine", and "Ionotropic Glutamate Receptor Complex"}

The other GO categories "synapse", "dendritic spine", and "ionotropic glutamate receptor complex" included mRNAs encoding postsynaptic proteins such as Arc, Kcnab2, Crtc1, Ncs1, Camk2a, Cdk16, Shank1, Homer2, Dlg2, Dlg4, Dlgap3, Sipa111, and Psd3 (Figure 2b,c). Most of these are known to play key roles in synaptic plasticity and higher-order brain functions (Supplementary Table S1). Arc accumulates at inactive synapses to prevent their enhancement and is involved in memory formation and neuronal diseases such as fragile X syndrome and Alzheimer's disease [21-26]. Kcnab2, a potassium voltage-gated channel subunit, interacts with Shank3, and mice deficient in Kcnab2 exhibit amygdala hyperexcitability and impaired associative learning and memory [92,93]. Crtc1 is a CREB-regulated transcription factor that is transported from the synapse to the nucleus in response to late-phase LTP (L-LTP), where it enhances spatial memory and memory consolidation/reconsolidation, and its deficiency in mice showed depression-like behaviors and impaired memory formation [44-49]. Ncs1 is a calcium-binding protein involved in short- and long-term synaptic plasticity, dopaminergic 
signaling, learning, and memory, and its dysfunction leads to various neuronal diseases such as schizophrenia, bipolar disorder, Parkinson's disease, and fragile $X$ syndrome [97-99]. Camk2a is a calcium/calmodulin-dependent protein kinase subunit that plays key roles in synaptic plasticity, AMPA receptor transmission, LTP, and long-term memory formation, and its dysfunction underlies neuropsychiatric disorders such as schizophrenia, epilepsy, and fragile $X$ syndrome [35-42]. Cdk16, a cyclin-dependent kinase, is responsible for dendrite development [43]. Shank1, Homer2, Dlg2, and Dlg4 are scaffold proteins of excitatory postsynaptic density. Shank1 regulates spine morphology and neurotransmission and is associated with ASD and neuropsychiatric disorders [156-160]. Homer2 interacts with dendritic spine actin regulators such as Cdc42 and drebrin, enhances cell surface expression of NMDA receptors, and is involved in spine maturation. Homer2 also interacts with amyloid precursor protein to inhibit A $\beta$ production [86-89]. Dlg2 is associated with neurodevelopmental disorders, its deficiency in mice causes LTP impairment and hypersocial behavior, and its overexpression improves A $\beta$-mediated cognitive dysfunction [56-60]. Dlg4, also known as PSD-95, plays key roles in synaptic plasticity, spine growth, and AMPA and NMDA receptor regulation, and its dysfunction underlies neuropsychiatric disorders such as schizophrenia and autism [61,62]. Dlgap3, also known as SAPAP3, binds to Dlg4, regulates mGluR5-driven AMPA receptor trafficking, and its deficiency in mice exhibits obsessive-compulsive-disorder-like behaviors and altered ultrasonic vocalizations [63-66]. Sipa111 is a Rap GTPase-activating protein (GAP) involved in spine morphogenesis, homeostatic synaptic plasticity, learning, and memory, and its expression is altered by A $\beta$ treatment [161-173]. Finally, Psd3 is a guanine nucleotide exchange factor of ADP-ribosylation factor 6 (Arf6), but its neuronal function is unknown. Thus, these dendritic mRNA-encoded proteins are implicated in synaptic plasticity and learning and memory, well-known roles of local translation in dendrites.

Of note, Homer2 and Psd3 were also classified as proteins that contain membrane-bound pleckstrin-homology ( $\mathrm{PH})$ domain in the GO enrichment analysis, although the Benjamini value (0.0535) did not reach significance. The GO categories of "PH domain" and/or "PH-like domain" included Homer2, Psd3, Psd, Plekhm2, Sptbn2, and Arhgap25. Compared with soluble proteins that diffuse easily in the cytosol, membrane-associated proteins are difficult to diffuse freely due to physical obstacles and electrostatic interactions within the membrane [208]. PH domains bind to phosphoinositides, which provide such electrostatic interactions [208,209]. Therefore, local translation of membrane-associated proteins appears to be an effective way to deliver low-mobility proteins at the required time and place.

\section{3. mRNAs Bound to and Regulated by RNA-Binding Proteins of RNA Granules}

RNA-binding proteins in RNA granules play a variety of roles in regulating mRNA stability, localization, and translation in neurons. Among them, we focus on five RNA-binding proteins: fragile X mental retardation protein (FMRP), RNG105/Caprin1, Ras-GAP SH3 domain binding protein (G3BP), cytoplasmic polyadenylation element binding protein 1 (CPEB1), and staufen double-stranded RNA binding proteins 1 and 2 (Stau1 and Stau2), of which associated mRNAs have been relatively extensively identified, and as summarized below, their knockout $(\mathrm{KO}) /$ knockdown $(\mathrm{KD})$ in rodents are known to affect neural functions and higher-order brain functions, including memory formation.

\subsection{Effects of RNA-Binding Proteins of RNA Granules on Higher-Order Brain Functions}

FMRP is encoded by the Fmr1 gene, in which mutations cause fragile $X$ syndrome, a mental retardation disorder. FMRP regulates protein-synthesis-dependent synaptic plasticity, because Fmr1 KO mice exhibited enhanced metabotropic glutamate receptor (mGluR)-dependent long-term depression (LTD) that requires protein synthesis [210-212]. Although controversial, several studies reported the impact of FMRP on memory formation. Contextual fear memory in Fmr1 KO mice was both impaired [213-215] and unaffected [216]. Spatial memory in the Morris water maze (MWM) in Fmr1 KO mice was also both impaired $[217,218]$ and unaffected $[213,219,220]$. 
RNG105/Caprin1 is responsible for the formation and/or maintenance of dendrites and synaptic connections [221] and is essential for long-term memory formation. Even a slight deficiency of RNG105/Caprin1 in heterozygous mice impaired reversal learning in spatial learning tasks [222]. A more severe deficiency of RNG105/Caprin1 in forebrain-specific cKO mice significantly impaired long-term memory in both spatial MWM and contextual-fear-conditioning tasks [16].

G3BP plays a central role in the assembly of stress granules (SGs) in response to various types of stress [223,224]. G3BP1 KO mice showed impaired spatial working memory in the Y-maze test, but they had normal acquisition of nonspatial long-term memory in the passive avoidance test [225].

CPEB1 binds to cytoplasmic polyadenylation elements (CPEs) within the 3'UTR of mRNAs and mediates cytoplasmic polyadenylation of mRNAs to promote translation [226]. CPEB1 regulates synaptic plasticity as indicated by a deficit in LTP in CPEB1 KO mice [227]. CPEB1 KO mice showed normal acquisition and retention of MWM spatial memory and fear-conditioned contextual memory but reduced memory extinction in these tests [228].

Staufen is well known for its role in mRNA localization during Drosophila embryo development, whereas its orthologs are known to regulate synaptic plasticity in rodents: Stau1 and Stau2 are required for L-LTP and LTD, respectively $[229,230]$. Although Stau1 KO mice showed no abnormalities in memory formation [231], Stau2 deficiency affected several types of memory. Stau2 KD rats exhibited impairment in spatial working memory in a delayed matching to place task in the MWM and delayed nonmatching to place task in an eight-arm radial maze [232]. In addition, Stau2 KD rats showed deficits in temporal association memory in a trace fear conditioning task and spatial association memory in an inhibitory avoidance task [232]. Downregulation of Stau2 in mice displayed deficits in discriminating different spatial contexts in the Barnes maze task [233].

\subsection{Methods for Identifying RNA-Protein Interactions}

To better understand the mechanistic basis of the RNA-binding-protein-mediated regulation of biological functions, including brain functions, it is important to identify target mRNAs for RNA-binding proteins. Various methods have been developed for this purpose [234,235].

In one method, RNA-protein direct binding in vitro has been analyzed using systematic evolution of ligands by exponential enrichment (SELEX). In SELEX, binding cycles between RNA-binding proteins and RNA pools are repeated to select high-affinity RNAs, and these RNAs are amplified by reverse transcription PCR, which detects RNAs that bind to proteins with high probability [236-238].

Second, RNA-protein association in cells and tissues has been identified with RNA-immunoprecipitation (IP), UV-crosslinking IP (CLIP), and electrophoretic mobility shift assay (EMSA). In CLIP, UV irradiation of cells or tissues generates covalent bonds between RNA and RNA-binding proteins when they are in close proximity to each other, followed by co-IP of the RNA with the RNA-binding proteins [239-241]. Other modified CLIP methods have been developed, such as high-throughput sequencing CLIP (HITS-CLIP) and photoactivatable ribonucleoside-enhanced CLIP (PAR-CLIP). HITS-CLIP is a combination of CLIP and high-throughput sequencing that enables comprehensive identification of associated RNAs [240,241]. In PAR-CLIP, RNA is labeled with photoreactive nucleoside analogs, and cells are irradiated with $365 \mathrm{~nm}$ UV. As a result, crosslinking efficiency is improved compared with conventional CLIP [240]. In EMSA, labeled RNA pools are incubated with cell and tissue extracts, and the binding of RNA to proteins can be detected by reduced mobility of the RNA in gel electrophoresis [242,243].

Third, RNA-protein association has also been identified using gene overexpression, $\mathrm{KD}$, and $\mathrm{KO}$ of RNA-binding proteins in cells and animals. These altered expression levels affect the stability, localization, and translation efficiency of the target mRNAs depending on the effect of the RNA-binding proteins on the mRNAs. Differential analysis of these changes compared with control cells and animals, using microarrays, RNA-seq, ribosome footprints, and their combination with the isolation of specific regions of cells, can identify mRNAs regulated by RNA-binding proteins. There are also various other 
methods to analyze RNA-protein associations, such as sequence- and structure-based methods using computational approaches [235].

Using these methods, target mRNAs of RNA-binding proteins in RNA granules have been identified. We comprehensively list the target mRNAs of FMRP, RNG105/Caprin1, G3BP, CPEB1, Stau1, and Stau2 and summarize the effects of the RNA-binding proteins on the mRNAs (Table 1 and Supplementary Table S2a-e). Furthermore, we compared the list of the dendritic mRNAs (Supplementary Table S1) with the target mRNAs of the RNA-binding proteins (Supplementary Table S2a-e) to find dendritic mRNAs that are associated with and/or regulated by FMRP, RNG105/Caprin1, G3BP, CPEB1, Stau1, and Stau2 (Supplementary Table S1). In the following subsection, we discuss how the RNA-binding proteins regulate their target mRNAs during mRNA localization and local translation in dendrites.

\subsection{Effects of the RNA-Binding Proteins on mRNA Regulation}

FMRP target mRNAs have been identified in many studies and are listed in Supplementary Table S2a [244-304]. FMRP has various effects on mRNA regulation such as mRNA expression, stability, localization, and translation, among which the major role of FMRP is translational regulation, as shown in a number of studies (Supplementary Table S2a). FMRP represses translation through multiple mechanisms in the basal state, but the repression is relieved by dephosphorylation of FMRP upon mGluR stimulation (references in Supplementary Table S2a). CPEB1 also regulates translation of its target mRNAs. The CPEB1 target mRNAs are listed in Supplementary Table S2d [305-334]. CPEB1 represses translation in the basal state but is phosphorylated upon synaptic stimulation, thereby polyadenylating its target mRNAs and promoting translation (references in Supplementary Table S2d). In neurons, both FMRP and CPEB1 are localized in dendrites and in/near spines [335-338]. Given that many of the 78 dendritic mRNAs have been identified to be associated with FMRP and CPEB1 (i.e., 28 with FMRP and 11 with CPEB1 (Supplementary Table S1)), FMRP and CPEB1 may regulate activity-dependent translation of dendritic mRNAs in dendrites near spines.

In contrast, RNG105/Caprin1, for which target mRNAs are listed in Supplementary Table S2b [16,221,339-342], is involved in mRNA localization. RNG105/Caprin1-containing RNA granules are localized throughout the proximal to distal regions of dendrites [221,339]. RNG105 cKO reduced the dendritic localization of many (46 of 78) of the dendritic mRNAs (Supplementary Table S1) [16]. This suggests that RNG105 plays an important role in mRNA localization to proximal and distal dendrites to achieve local translation, which may be necessary for the formation of long-term memory. In addition to mRNA localization, RNG105/Caprin1 may play a role in spatially biasing translation to RNA granules: overexpression of RNG105/Caprin1 in cells locally increased translation in/near RNA granules but suppressed translation in the cytoplasm [343]. Staufen also regulates mRNA localization in addition to participating in mRNA decay, known as Staufen-mediated mRNA decay. The target mRNAs of Staufen are listed in Supplementary Table S2e [230,312,344-360]. Of the 78 dendritic mRNAs, 44 were associated with Stau1 and/or Stau2 (Supplementary Table S1). Although both Stau1 and Stau2 show dendritic localization in neurons, Stau2 is localized to more distal dendrites than Stau1 [361]. It was reported that some dendritic mRNAs are restricted to proximal dendrites, but others are localized not only to proximal but also distal dendrites [15]. Given the different distributions along the proximal-distal dendritic axis of RNG105/Caprin1, Stau1, and Stau2, these RNA-binding proteins may regulate mRNA localization to the appropriate region of dendrites.

The association of G3BP with mRNA has been analyzed in several studies, including comprehensive identifications of G3BP-associated mRNAs (Supplementary Table S2c) [362-372]. However, no G3BP-associated mRNAs have been found in the 78 dendritic mRNAs (Supplementary Table S1). The dendritic mRNAs were identified in the hippocampus [15-17], but fibroblasts were used to comprehensively identify G3BP-associated mRNAs [370,371]. This difference in mRNA sources may be a reason for the absence of G3BP-associated mRNAs in dendritic mRNAs. Alternative reasons may come from the G3BP distribution pattern in neurons: although G3BP is localized to dendrites 
in addition to the soma in primary cultured neurons [221], G3BP is almost restricted to the soma in hippocampal CA1 pyramidal neurons in vivo [225]. Thus, G3BP may preferentially target somatic mRNAs rather than dendritic mRNAs in hippocampal pyramidal neurons. It should also be noted that G3BP is a key protein that facilitates the assembly of SGs, of which many components are shared with neuronal RNA granules. SGs are formed only under stress, but neuronal RNA granules are always present, even when neurons are unstressed. Arsenite treatment of neurons that already have RNA granules has been reported to induce the assembly of another population of granules containing RNA-binding proteins such as G3BP, TIAR, and FMRP [129,373,374]. Thus, stress-induced granules may differ from granules present in unstressed neurons. In this case, G3BP may primarily target mRNAs in SGs rather than regulating dendritic mRNAs for neuronal synaptic plasticity.

Each RNA-binding protein has its own functions that regulate the expression, stability, localization, and translation of its target mRNAs. In addition to executing these intrinsic functions, RNA-binding proteins in RNA granules may also play roles in regulating mRNAs through controlling the condensation and dissolution of RNA granules. Recently, it has been revealed that RNA granules are formed by liquid-liquid phase separation and their liquid-like and solid-like states can be dynamically controlled [375-381]. Each RNA-binding protein exhibits different dynamics in RNA granules, and their combinations in RNA granules affect the physical properties of RNA granules and the translation efficiency in/near RNA granules [343]. Understanding the effects of physical properties and condensation/dissolution behavior of RNA-binding proteins on mRNA regulation may be also important to better understand the mechanistic basis of mRNA localization and local translation in neurons.

\section{Future Perspectives}

The functions of RNA-binding proteins have been revealed in many studies. In addition, their target and dendritic mRNAs have been identified, and the functions of the proteins encoded by these mRNAs have been elucidated. However, there is limited understanding of the physiological relevance of locally increasing the concentration of mRNA-encoded proteins through mRNA localization and local translation. Exceptionally, Camk2a mRNA localization to dendrites has been reported to be required for L-LTP and long-term memory formation. This was revealed by the deletion of the 3'UTR, which caused a loss of dendritic localization of Camk2a mRNA but did not affect its translation [382]. However, the relevance of such local regulation of most other dendritic mRNAs to synaptic plasticity and brain functions remains elusive. To determine this, high-throughput methods cannot be used, and each mRNA has to be analyzed individually. Nevertheless, recent advances in comprehensive identification technology have identified a large number of candidates for dendritic mRNAs and RNA-binding protein target mRNAs, and selective ones need to be prioritized. In this review, we have catalogued and selected mRNAs that are localized to dendrites and regulated by RNA-binding proteins in RNA granules. A future challenge in this research field is to elucidate the biological and physiological relevance of local regulation of gene expression, which can be solved by artificially manipulating local regulation, such as altering mRNA localization without affecting translation efficiency and affecting RNA granule assembly without losing essential functions of RNA-binding proteins. We hope this review will help researchers in this field find gemstones in the wilderness.

Supplementary Materials: The following are available online at http://www.mdpi.com/2218-273X/10/2/167/s1, Table S1: Dendritic mRNAs and their associated RNA-binding proteins. Table S2a: FMRP target mRNAs. Table S2b: RNG105/Caprin1 target mRNAs. Table S2c: G3BP target mRNAs. Table S2d: CPEB1 target mRNAs. Table S2e: Staufen, Stau1 and Stau2 target mRNAs.

Author Contributions: Conceptualization, R.O. and N.S.; Analysis, R.O. and N.S.; Writing-original draft, R.O.; Writing-review and editing, N.S.; Supervision, N.S. All authors have read and agreed to the published version of the manuscript.

Funding: This work was supported by Grant-in-Aid for Scientific Research from the Japan Society for the Promotion of Science (JSPS) (19H03161 (N.S.)) and Grant-in-Aid for JSPS fellows (19J01826 (R.O.)). 
Conflicts of Interest: The authors declare no conflict of interest.

\section{References}

1. Martin, K.C.; Ephrussi, A. mRNA localization: Gene expression in the spatial dimension. Cell 2009, 136, 719-730. [CrossRef] [PubMed]

2. Costa-Mattioli, M.; Sossin, W.S.; Klann, E.; Sonenberg, N. Translational control of long-lasting synaptic plasticity and memory. Neuron 2009, 61, 10-26. [CrossRef] [PubMed]

3. Sutton, M.A.; Schuman, E.M. Dendritic protein synthesis, synaptic plasticity, and memory. Cell 2006, 127, 49-58. [CrossRef] [PubMed]

4. Cioni, J.-M.; Koppers, M.; Holt, C.E. Molecular control of local translation in axon development and maintenance. Curr. Opin. Neurobiol. 2018, 51, 86-94. [CrossRef] [PubMed]

5. Kang, H.; Schuman, E.M. A requirement for local protein synthesis in neurotrophin-induced hippocampal synaptic plasticity. Science 1996, 273, 1402-1406. [CrossRef]

6. Krichevsky, A.M.; Kosik, K.S. Neuronal RNA granules: A link between RNA localization and stimulation-dependent translation. Neuron 2001, 32, 683-696. [CrossRef]

7. Kiebler, M.A.; Bassell, G.J. Neuronal RNA granules: Movers and makers. Neuron 2006, 51, 685-690. [CrossRef]

8. Bramham, C.R.; Wells, D.G. Dendritic mRNA: Transport, translation and function. Nat. Rev. Neurosci. 2007, 8,776-789. [CrossRef]

9. Wang, W.; van Niekerk, E.; Willis, D.E.; Twiss, J.L. RNA transport and localized protein synthesis in neurological disorders and neural repair. Dev. Neurobiol. 2007, 67, 1166-1182. [CrossRef]

10. Sudhakaran, I.P.; Ramaswami, M. Long-term memory consolidation: The role of RNA-binding proteins with prion-like domains. RNA Biol. 2017, 14, 568-586. [CrossRef]

11. Kuhl, D.; Skehel, P. Dendritic localization of mRNAs. Curr. Opin. Neurobiol. 1998, 8, 600-606. [CrossRef]

12. Steward, O.; Schuman, E.M. Protein synthesis at synaptic sites on dendrites. Annu. Rev. Neurosci. 2001, 24, 299-325. [CrossRef] [PubMed]

13. Poon, M.M.; Choi, S.-H.; Jamieson, C.A.M.; Geschwind, D.H.; Martin, K.C. Identification of process-localized mRNAs from cultured rodent hippocampal neurons. J. Neurosci. 2006, 26, 13390-13399. [CrossRef]

14. Zhong, J.; Zhang, T.; Bloch, L.M. Dendritic mRNAs encode diversified functionalities in hippocampal pyramidal neurons. BMC Neurosci. 2006, 7, 17. [CrossRef] [PubMed]

15. Cajigas, I.J.; Tushev, G.; Will, T.J.; tom Dieck, S.; Fuerst, N.; Schuman, E.M. The local transcriptome in the synaptic neuropil revealed by deep sequencing and high-resolution imaging. Neuron 2012, 74, 453-466. [CrossRef]

16. Nakayama, K.; Ohashi, R.; Shinoda, Y.; Yamazaki, M.; Abe, M.; Fujikawa, A.; Shigenobu, S.; Futatsugi, A.; Noda, M.; Mikoshiba, K.; et al. RNG105/caprin1, an RNA granule protein for dendritic mRNA localization, is essential for long-term memory formation. Elife 2017, 6. [CrossRef]

17. Ainsley, J.A.; Drane, L.; Jacobs, J.; Kittelberger, K.A.; Reijmers, L.G. Functionally diverse dendritic mRNAs rapidly associate with ribosomes following a novel experience. Nat. Commun. 2014, 5, 4510. [CrossRef]

18. Farris, S.; Ward, J.M.; Carstens, K.E.; Samadi, M.; Wang, Y.; Dudek, S.M. Hippocampal Subregions Express Distinct Dendritic Transcriptomes that Reveal Differences in Mitochondrial Function in CA2. Cell Rep. 2019, 29, 522-539.e6. [CrossRef]

19. Wang, H.; Ferguson, G.D.; Pineda, V.V.; Cundiff, P.E.; Storm, D.R. Overexpression of type-1 adenylyl cyclase in mouse forebrain enhances recognition memory and LTP. Nat. Neurosci. 2004, 7, 635-642. [CrossRef]

20. Garelick, M.G.; Chan, G.C.K.; DiRocco, D.P.; Storm, D.R. Overexpression of type I adenylyl cyclase in the forebrain impairs spatial memory in aged but not young mice. J. Neurosci. 2009, 29, 10835-10842. [CrossRef]

21. Korb, E.; Finkbeiner, S. Arc in synaptic plasticity: From gene to behavior. Trends Neurosci. 2011, 34, 591-598. [CrossRef] [PubMed]

22. Nikolaienko, O.; Patil, S.; Eriksen, M.S.; Bramham, C.R. Arc protein: A flexible hub for synaptic plasticity and cognition. Semin. Cell Dev. Biol. 2018, 77, 33-42. [CrossRef] [PubMed]

23. Newpher, T.M.; Harris, S.; Pringle, J.; Hamilton, C.; Soderling, S. Regulation of spine structural plasticity by Arc/Arg3.1. Semin. Cell Dev. Biol. 2018, 77, 25-32. [CrossRef] [PubMed]

24. Tzingounis, A.V.; Nicoll, R.A. Arc/Arg3.1: Linking gene expression to synaptic plasticity and memory. Neuron 2006, 52, 403-407. [CrossRef] 
25. Shepherd, J.D.; Bear, M.F. New views of Arc, a master regulator of synaptic plasticity. Nat. Neurosci. 2011, 14, 279-284. [CrossRef]

26. Okuno, H.; Minatohara, K.; Bito, H. Inverse synaptic tagging: An inactive synapse-specific mechanism to capture activity-induced Arc/arg3.1 and to locally regulate spatial distribution of synaptic weights. Semin. Cell Dev. Biol. 2018, 77, 43-50. [CrossRef]

27. Yoshihara, T.; Sugihara, K.; Kizuka, Y.; Oka, S.; Asano, M. Learning/memory impairment and reduced expression of the HNK-1 carbohydrate in beta4-galactosyltransferase-II-deficient mice. J. Biol. Chem. 2009, 284, 12550-12561. [CrossRef]

28. Ohta, T.; Ohba, T.; Suzuki, T.; Watanabe, H.; Sasano, H.; Murakami, M. Decreased calcium channel currents and facilitated epinephrine release in the Ca2+ channel beta3 subunit-null mice. Biochem. Biophys. Res. Commun. 2010, 394, 464-469. [CrossRef]

29. Belkacemi, A.; Hui, X.; Wardas, B.; Laschke, M.W.; Wissenbach, U.; Menger, M.D.; Lipp, P.; Beck, A.; Flockerzi, V. IP3 Receptor-Dependent Cytoplasmic Ca2+ Signals Are Tightly Controlled by Cav $\beta 3$. Cell Rep. 2018, 22, 1339-1349. [CrossRef]

30. Namkung, Y.; Smith, S.M.; Lee, S.B.; Skrypnyk, N.V.; Kim, H.L.; Chin, H.; Scheller, R.H.; Tsien, R.W.; Shin, H.S. Targeted disruption of the Ca2+ channel beta3 subunit reduces $\mathrm{N}$ - and L-type Ca2+ channel activity and alters the voltage-dependent activation of P/Q-type Ca2+ channels in neurons. Proc. Natl. Acad. Sci. USA 1998, 95, 12010-12015. [CrossRef]

31. Jeon, D.; Song, I.; Guido, W.; Kim, K.; Kim, E.; Oh, U.; Shin, H.-S. Ablation of Ca2+ channel beta3 subunit leads to enhanced N-methyl-D-aspartate receptor-dependent long term potentiation and improved long term memory. J. Biol. Chem. 2008, 283, 12093-12101. [CrossRef] [PubMed]

32. Murakami, M.; Nakagawasai, O.; Yanai, K.; Nunoki, K.; Tan-No, K.; Tadano, T.; Iijima, T. Modified behavioral characteristics following ablation of the voltage-dependent calcium channel beta3 subunit. Brain Res. 2007, 1160, 102-112. [CrossRef] [PubMed]

33. Griessmeier, K.; Cuny, H.; Rötzer, K.; Griesbeck, O.; Harz, H.; Biel, M.; Wahl-Schott, C. Calmodulin is a functional regulator of Cav1.4 L-type Ca2+ channels. J. Biol. Chem. 2009, 284, 29809-29816. [CrossRef] [PubMed]

34. Hisatsune, C.; Umemori, H.; Inoue, T.; Michikawa, T.; Kohda, K.; Mikoshiba, K.; Yamamoto, T. Phosphorylation-dependent regulation of N-methyl-D-aspartate receptors by calmodulin. J. Biol. Chem. 1997, 272, 20805-20810. [CrossRef]

35. Miyamoto, E.; Fukunaga, K. A role of $\mathrm{Ca} 2+/$ calmodulin-dependent protein kinase II in the induction of long-term potentiation in hippocampal CA1 area. Neurosci. Res. 1996, 24, 117-122. [CrossRef]

36. Zalcman, G.; Federman, N.; Romano, A. CaMKII Isoforms in Learning and Memory: Localization and Function. Front. Mol. Neurosci. 2018, 11, 445. [CrossRef]

37. Colbran, R.J.; Brown, A.M. Calcium/calmodulin-dependent protein kinase II and synaptic plasticity. Curr. Opin. Neurobiol. 2004, 14, 318-327. [CrossRef]

38. Fink, C.C.; Meyer, T. Molecular mechanisms of CaMKII activation in neuronal plasticity. Curr. Opin. Neurobiol. 2002, 12, 293-299. [CrossRef]

39. Ataei, N.; Sabzghabaee, A.M.; Movahedian, A. Calcium/Calmodulin-dependent Protein Kinase II is a Ubiquitous Molecule in Human Long-term Memory Synaptic Plasticity: A Systematic Review. Int. J. Prev. Med. 2015, 6, 88 .

40. Lisman, J.; Schulman, H.; Cline, H. The molecular basis of CaMKII function in synaptic and behavioural memory. Nat. Rev. Neurosci. 2002, 3, 175-190. [CrossRef]

41. Hell, J.W. CaMKII: Claiming center stage in postsynaptic function and organization. Neuron 2014, 81, $249-265$. [CrossRef] [PubMed]

42. Robison, A.J. Emerging role of CaMKII in neuropsychiatric disease. Trends Neurosci. 2014, 37, 653-662. [CrossRef] [PubMed]

43. Fu, W.-Y.; Cheng, K.; Fu, A.K.Y.; Ip, N.Y. Cyclin-dependent kinase 5-dependent phosphorylation of Pctaire1 regulates dendrite development. Neuroscience 2011, 180, 353-359. [CrossRef] [PubMed]

44. Sekeres, M.J.; Mercaldo, V.; Richards, B.; Sargin, D.; Mahadevan, V.; Woodin, M.A.; Frankland, P.W.; Josselyn, S.A. Increasing CRTC1 function in the dentate gyrus during memory formation or reactivation increases memory strength without compromising memory quality. J. Neurosci. 2012, 32, 17857-17868. [CrossRef] 
45. Ch'ng, T.H.; Uzgil, B.; Lin, P.; Avliyakulov, N.K.; O’Dell, T.J.; Martin, K.C. Activity-dependent transport of the transcriptional coactivator CRTC1 from synapse to nucleus. Cell 2012, 150, 207-221. [CrossRef]

46. Parra-Damas, A.; Valero, J.; Chen, M.; España, J.; Martín, E.; Ferrer, I.; Rodríguez-Alvarez, J.; Saura, C.A. Crtc1 activates a transcriptional program deregulated at early Alzheimer's disease-related stages. J. Neurosci. 2014, 34, 5776-5787. [CrossRef]

47. Breuillaud, L.; Rossetti, C.; Meylan, E.M.; Mérinat, C.; Halfon, O.; Magistretti, P.J.; Cardinaux, J.-R. Deletion of CREB-regulated transcription coactivator 1 induces pathological aggression, depression-related behaviors, and neuroplasticity genes dysregulation in mice. Biol. Psychiatry 2012, 72, 528-536. [CrossRef]

48. Nonaka, M.; Kim, R.; Fukushima, H.; Sasaki, K.; Suzuki, K.; Okamura, M.; Ishii, Y.; Kawashima, T.; Kamijo, S.; Takemoto-Kimura, S.; et al. Region-specific activation of CRTC1-CREB signaling mediates long-term fear memory. Neuron 2014, 84, 92-106. [CrossRef]

49. Parra-Damas, A.; Chen, M.; Enriquez-Barreto, L.; Ortega, L.; Acosta, S.; Perna, J.C.; Fullana, M.N.; Aguilera, J.; Rodríguez-Alvarez, J.; Saura, C.A. CRTC1 Function During Memory Encoding Is Disrupted in Neurodegeneration. Biol. Psychiatry 2017, 81, 111-123. [CrossRef]

50. Li, D.-P.; Zhou, J.-J.; Pan, H.-L. Endogenous casein kinase-1 modulates NMDA receptor activity of hypothalamic presympathetic neurons and sympathetic outflow in hypertension. J. Physiol. (Lond.) 2015, 593, 4439-4452. [CrossRef]

51. Chergui, K.; Svenningsson, P.; Greengard, P. Physiological role for casein kinase 1 in glutamatergic synaptic transmission. J. Neurosci. 2005, 25, 6601-6609. [CrossRef] [PubMed]

52. Gross, S.D.; Hoffman, D.P.; Fisette, P.L.; Baas, P.; Anderson, R.A. A phosphatidylinositol 4,5-bisphosphatesensitive casein kinase I alpha associates with synaptic vesicles and phosphorylates a subset of vesicle proteins. J. Cell Biol. 1995, 130, 711-724. [CrossRef] [PubMed]

53. Yinan, M.; Yu, Q.; Zhiyue, C.; Jianjun, L.; Lie, H.; Liping, Z.; Jianhui, Z.; Fang, S.; Dingfang, B.; Qing, L.; et al. Polymorphisms of casein kinase I gamma 2 gene associated with simple febrile seizures in Chinese Han population. Neurosci. Lett. 2004, 368, 2-6. [CrossRef] [PubMed]

54. Ji, Z.; Li, H.; Yang, Z.; Huang, X.; Ke, X.; Ma, S.; Lin, Z.; Lu, Y.; Zhang, M. Kibra Modulates Learning and Memory via Binding to Dendrin. Cell Rep. 2019, 26, 2064-2077.e7. [CrossRef]

55. Kremerskothen, J.; Kindler, S.; Finger, I.; Veltel, S.; Barnekow, A. Postsynaptic recruitment of Dendrin depends on both dendritic mRNA transport and synaptic anchoring. J. Neurochem. 2006, 96, 1659-1666. [CrossRef]

56. Reggiani, C.; Coppens, S.; Sekhara, T.; Dimov, I.; Pichon, B.; Lufin, N.; Addor, M.-C.; Belligni, E.F.; Digilio, M.C.; Faletra, F.; et al. Novel promoters and coding first exons in DLG2 linked to developmental disorders and intellectual disability. Genome Med. 2017, 9, 67. [CrossRef]

57. Winkler, D.; Daher, F.; Wüstefeld, L.; Hammerschmidt, K.; Poggi, G.; Seelbach, A.; Krueger-Burg, D.; Vafadari, B.; Ronnenberg, A.; Liu, Y.; et al. Hypersocial behavior and biological redundancy in mice with reduced expression of PSD95 or PSD93. Behav. Brain Res. 2018, 352, 35-45. [CrossRef]

58. Parker, M.J.; Zhao, S.; Bredt, D.S.; Sanes, J.R.; Feng, G. PSD93 regulates synaptic stability at neuronal cholinergic synapses. J. Neurosci. 2004, 24, 378-388. [CrossRef]

59. Yu, L.; Liu, Y.; Yang, H.; Zhu, X.; Cao, X.; Gao, J.; Zhao, H.; Xu, Y. PSD-93 Attenuates Amyloid- $\beta$-Mediated Cognitive Dysfunction by Promoting the Catabolism of Amyloid- $\beta$. J. Alzheimers Dis. 2017, 59, 913-927. [CrossRef]

60. Carlisle, H.J.; Fink, A.E.; Grant, S.G.N.; O'Dell, T.J. Opposing effects of PSD-93 and PSD-95 on long-term potentiation and spike timing-dependent plasticity. J. Physiol. (Lond.) 2008, 586, 5885-5900. [CrossRef]

61. Iasevoli, F.; Tomasetti, C.; de Bartolomeis, A. Scaffolding proteins of the post-synaptic density contribute to synaptic plasticity by regulating receptor localization and distribution: Relevance for neuropsychiatric diseases. Neurochem. Res. 2013, 38, 1-22. [CrossRef] [PubMed]

62. Coley, A.A.; Gao, W.-J. PSD95: A synaptic protein implicated in schizophrenia or autism? Prog. Neuropsychopharmacol. Biol. Psychiatry 2018, 82, 187-194. [CrossRef] [PubMed]

63. Wan, Y.; Feng, G.; Calakos, N. Sapap3 deletion causes mGluR5-dependent silencing of AMPAR synapses. J. Neurosci. 2011, 31, 16685-16691. [CrossRef] [PubMed]

64. Chen, M.; Wan, Y.; Ade, K.; Ting, J.; Feng, G.; Calakos, N. Sapap3 deletion anomalously activates short-term endocannabinoid-mediated synaptic plasticity. J. Neurosci. 2011, 31, 9563-9573. [CrossRef] [PubMed] 
65. Welch, J.M.; Lu, J.; Rodriguiz, R.M.; Trotta, N.C.; Peca, J.; Ding, J.-D.; Feliciano, C.; Chen, M.; Adams, J.P.; Luo, J.; et al. Cortico-striatal synaptic defects and OCD-like behaviours in Sapap3-mutant mice. Nature 2007, 448, 894-900. [CrossRef] [PubMed]

66. Tesdahl, N.S.; King, D.K.; McDaniel, L.N.; Pieper, A.A. Altered ultrasonic vocalization in neonatal SAPAP3-deficient mice. Neuroreport 2017, 28, 1115-1118. [CrossRef]

67. Beckelman, B.C.; Zhou, X.; Keene, C.D.; Ma, T. Impaired Eukaryotic Elongation Factor 1A Expression in Alzheimer's Disease. Neurodegener. Dis. 2016, 16, 39-43. [CrossRef]

68. Tsokas, P.; Grace, E.A.; Chan, P.; Ma, T.; Sealfon, S.C.; Iyengar, R.; Landau, E.M.; Blitzer, R.D. Local protein synthesis mediates a rapid increase in dendritic elongation factor $1 \mathrm{~A}$ after induction of late long-term potentiation. J. Neurosci. 2005, 25, 5833-5843. [CrossRef]

69. Najmabadi, H.; Hu, H.; Garshasbi, M.; Zemojtel, T.; Abedini, S.S.; Chen, W.; Hosseini, M.; Behjati, F.; Haas, S.; Jamali, P.; et al. Deep sequencing reveals 50 novel genes for recessive cognitive disorders. Nature 2011, 478, 57-63. [CrossRef]

70. Heise, C.; Gardoni, F.; Culotta, L.; di Luca, M.; Verpelli, C.; Sala, C. Elongation factor-2 phosphorylation in dendrites and the regulation of dendritic mRNA translation in neurons. Front. Cell. Neurosci. 2014, 8, 35. [CrossRef]

71. Martinetz, S.; Meinung, C.-P.; Jurek, B.; von Schack, D.; van den Burg, E.H.; Slattery, D.A.; Neumann, I.D. De Novo Protein Synthesis Mediated by the Eukaryotic Elongation Factor 2 Is Required for the Anxiolytic Effect of Oxytocin. Biol. Psychiatry 2019, 85, 802-811. [CrossRef] [PubMed]

72. Li, X.; Alafuzoff, I.; Soininen, H.; Winblad, B.; Pei, J.-J. Levels of mTOR and its downstream targets 4E-BP1, eEF2, and eEF2 kinase in relationships with tau in Alzheimer's disease brain. FEBS J. 2005, 272, 4211-4220. [CrossRef] [PubMed]

73. Iizuka, A.; Sengoku, K.; Iketani, M.; Nakamura, F.; Sato, Y.; Matsushita, M.; Nairn, A.C.; Takamatsu, K.; Goshima, Y.; Takei, K. Calcium-induced synergistic inhibition of a translational factor eEF2 in nerve growth cones. Biochem. Biophys. Res. Commun. 2007, 353, 244-250. [CrossRef] [PubMed]

74. Sutton, M.A.; Taylor, A.M.; Ito, H.T.; Pham, A.; Schuman, E.M. Postsynaptic decoding of neural activity: eEF2 as a biochemical sensor coupling miniature synaptic transmission to local protein synthesis. Neuron 2007, 55, 648-661. [CrossRef] [PubMed]

75. Park, S.; Park, J.M.; Kim, S.; Kim, J.-A.; Shepherd, J.D.; Smith-Hicks, C.L.; Chowdhury, S.; Kaufmann, W.; Kuhl, D.; Ryazanov, A.G.; et al. Elongation factor 2 and fragile $X$ mental retardation protein control the dynamic translation of Arc/Arg3.1 essential for mGluR-LTD. Neuron 2008, 59, 70-83. [CrossRef] [PubMed]

76. Takei, N.; Kawamura, M.; Ishizuka, Y.; Kakiya, N.; Inamura, N.; Namba, H.; Nawa, H. Brain-derived neurotrophic factor enhances the basal rate of protein synthesis by increasing active eukaryotic elongation factor 2 levels and promoting translation elongation in cortical neurons. J. Biol. Chem. 2009, 284, 26340-26348. [CrossRef]

77. Verpelli, C.; Piccoli, G.; Zibetti, C.; Zanchi, A.; Gardoni, F.; Huang, K.; Brambilla, D.; Di Luca, M.; Battaglioli, E.; Sala, C. Synaptic activity controls dendritic spine morphology by modulating eEF2-dependent BDNF synthesis. J. Neurosci. 2010, 30, 5830-5842. [CrossRef]

78. McCamphill, P.K.; Farah, C.A.; Anadolu, M.N.; Hoque, S.; Sossin, W.S. Bidirectional regulation of eEF2 phosphorylation controls synaptic plasticity by decoding neuronal activity patterns. J. Neurosci. 2015, 35, 4403-4417. [CrossRef]

79. Martin, H.C.; Jones, W.D.; McIntyre, R.; Sanchez-Andrade, G.; Sanderson, M.; Stephenson, J.D.; Jones, C.P.; Handsaker, J.; Gallone, G.; Bruntraeger, M.; et al. Quantifying the contribution of recessive coding variation to developmental disorders. Science 2018, 362, 1161-1164. [CrossRef]

80. Del Prete, D.; Rice, R.C.; Rajadhyaksha, A.M.; D'Adamio, L. Amyloid Precursor Protein (APP) May Act as a Substrate and a Recognition Unit for CRL4CRBN and Stub1 E3 Ligases Facilitating Ubiquitination of Proteins Involved in Presynaptic Functions and Neurodegeneration. J. Biol. Chem. 2016, 291, 17209-17227. [CrossRef]

81. Smith, A.R.; Smith, R.G.; Pishva, E.; Hannon, E.; Roubroeks, J.A.Y.; Burrage, J.; Troakes, C.; Al-Sarraj, S.; Sloan, C.; Mill, J.; et al. Parallel profiling of DNA methylation and hydroxymethylation highlights neuropathology-associated epigenetic variation in Alzheimer's disease. Clin. Epigenetics 2019, 11, 52. [CrossRef] [PubMed] 
82. Gokoffski, K.K.; Wu, H.-H.; Beites, C.L.; Kim, J.; Kim, E.J.; Matzuk, M.M.; Johnson, J.E.; Lander, A.D.; Calof, A.L. Activin and GDF11 collaborate in feedback control of neuroepithelial stem cell proliferation and fate. Development 2011, 138, 4131-4142. [CrossRef] [PubMed]

83. Augustin, H.; McGourty, K.; Steinert, J.R.; Cochemé, H.M.; Adcott, J.; Cabecinha, M.; Vincent, A.; Halff, E.F.; Kittler, J.T.; Boucrot, E.; et al. Myostatin-like proteins regulate synaptic function and neuronal morphology. Development 2017, 144, 2445-2455. [CrossRef]

84. Shi, Y.; Liu, J.-P. Gdf11 facilitates temporal progression of neurogenesis in the developing spinal cord. J. Neurosci. 2011, 31, 883-893. [CrossRef] [PubMed]

85. Phiel, C.J.; Wilson, C.A.; Lee, V.M.-Y.; Klein, P.S. GSK-3alpha regulates production of Alzheimer's disease amyloid-beta peptides. Nature 2003, 423, 435-439. [CrossRef] [PubMed]

86. Parisiadou, L.; Bethani, I.; Michaki, V.; Krousti, K.; Rapti, G.; Efthimiopoulos, S. Homer2 and Homer3 interact with amyloid precursor protein and inhibit Abeta production. Neurobiol. Dis. 2008, 30, 353-364. [CrossRef]

87. Smothers, C.T.; Szumlinski, K.K.; Worley, P.F.; Woodward, J.J. Altered NMDA receptor function in primary cultures of hippocampal neurons from mice lacking the Homer2 gene. Synapse 2016, 70, 33-39. [CrossRef]

88. Shiraishi-Yamaguchi, Y.; Sato, Y.; Sakai, R.; Mizutani, A.; Knöpfel, T.; Mori, N.; Mikoshiba, K.; Furuichi, T. Interaction of Cupidin/Homer2 with two actin cytoskeletal regulators, Cdc42 small GTPase and Drebrin, in dendritic spines. BMC Neurosci. 2009, 10, 25. [CrossRef]

89. McGuier, N.S.; Padula, A.E.; Mulholland, P.J.; Chandler, L.J. Homer2 deletion alters dendritic spine morphology but not alcohol-associated adaptations in GluN2B-containing N-methyl-D-aspartate receptors in the nucleus accumbens. Front. Pharmacol. 2015, 6, 28. [CrossRef]

90. Lamprecht, R.; Dracheva, S.; Assoun, S.; LeDoux, J.E. Fear conditioning induces distinct patterns of gene expression in lateral amygdala. Genes Brain Behav. 2009, 8, 735-743. [CrossRef]

91. Few, A.P.; Lautermilch, N.J.; Westenbroek, R.E.; Scheuer, T.; Catterall, W.A. Differential regulation of CaV2.1 channels by calcium-binding protein 1 and visinin-like protein-2 requires $\mathrm{N}$-terminal myristoylation. J. Neurosci. 2005, 25, 7071-7080. [CrossRef] [PubMed]

92. Proepper, C.; Putz, S.; Russell, R.; Boeckers, T.M.; Liebau, S. The Kv $\beta 2$ subunit of voltage-gated potassium channels is interacting with ProSAP2/Shank3 in the PSD. Neuroscience 2014, 261, 133-143. [CrossRef] [PubMed]

93. Perkowski, J.J.; Murphy, G.G. Deletion of the mouse homolog of KCNAB2, a gene linked to monosomy 1p36, results in associative memory impairments and amygdala hyperexcitability. J. Neurosci. 2011, 31, 46-54. [CrossRef] [PubMed]

94. Hanlon, D.W.; Yang, Z.; Goldstein, L.S. Characterization of KIFC2, a neuronal kinesin superfamily member in mouse. Neuron 1997, 18, 439-451. [CrossRef]

95. Saito, N.; Okada, Y.; Noda, Y.; Kinoshita, Y.; Kondo, S.; Hirokawa, N. KIFC2 is a novel neuron-specific C-terminal type kinesin superfamily motor for dendritic transport of multivesicular body-like organelles. Neuron 1997, 18, 425-438. [CrossRef]

96. Kelley, C.M.; Ginsberg, S.D.; Alldred, M.J.; Strupp, B.J.; Mufson, E.J. Maternal Choline Supplementation Alters Basal Forebrain Cholinergic Neuron Gene Expression in the Ts65Dn Mouse Model of Down Syndrome. Dev. Neurobiol. 2019, 79, 664-683. [CrossRef]

97. Bandura, J.; Feng, Z.-P. Current Understanding of the Role of Neuronal Calcium Sensor 1 in Neurological Disorders. Mol. Neurobiol. 2019, 56, 6080-6094. [CrossRef]

98. Nakamura, T.Y.; Nakao, S.; Wakabayashi, S. Emerging Roles of Neuronal Ca2+ Sensor-1 in Cardiac and Neuronal Tissues: A Mini Review. Front. Mol. Neurosci. 2019, 12, 56. [CrossRef]

99. Dason, J.S.; Romero-Pozuelo, J.; Atwood, H.L.; Ferrús, A. Multiple roles for frequenin/NCS-1 in synaptic function and development. Mol. Neurobiol. 2012, 45, 388-402. [CrossRef]

100. Heyne, H.O.; Lautenschläger, S.; Nelson, R.; Besnier, F.; Rotival, M.; Cagan, A.; Kozhemyakina, R.; Plyusnina, I.Z.; Trut, L.; Carlborg, Ö.; et al. Genetic influences on brain gene expression in rats selected for tameness and aggression. Genetics 2014, 198, 1277-1290. [CrossRef]

101. Yamada, M.; Toba, S.; Takitoh, T.; Yoshida, Y.; Mori, D.; Nakamura, T.; Iwane, A.H.; Yanagida, T.; Imai, H.; Yu-Lee, L.-Y.; et al. mNUDC is required for plus-end-directed transport of cytoplasmic dynein and dynactins by kinesin-1. EMBO J. 2010, 29, 517-531. [CrossRef] [PubMed]

102. Cappello, S.; Monzo, P.; Vallee, R.B. NudC is required for interkinetic nuclear migration and neuronal migration during neocortical development. Dev. Biol. 2011, 357, 326-335. [CrossRef] [PubMed] 
103. Aumais, J.P.; Tunstead, J.R.; McNeil, R.S.; Schaar, B.T.; McConnell, S.K.; Lin, S.H.; Clark, G.D.; Yu-Lee, L.Y. NudC associates with Lis1 and the dynein motor at the leading pole of neurons. J. Neurosci. 2001, 21, RC187. [CrossRef] [PubMed]

104. Cruchaga, C.; Karch, C.M.; Jin, S.C.; Benitez, B.A.; Cai, Y.; Guerreiro, R.; Harari, O.; Norton, J.; Budde, J.; Bertelsen, S.; et al. Rare coding variants in the phospholipase D3 gene confer risk for Alzheimer's disease. Nature 2014, 505, 550-554. [CrossRef]

105. Wang, J.; Yu, J.-T.; Tan, L. PLD3 in Alzheimer's disease. Mol. Neurobiol. 2015, 51, 480-486. [CrossRef]

106. Satoh, J.-I.; Kino, Y.; Yamamoto, Y.; Kawana, N.; Ishida, T.; Saito, Y.; Arima, K. PLD3 is accumulated on neuritic plaques in Alzheimer's disease brains. Alzheimers Res. Ther. 2014, 6, 70. [CrossRef]

107. Lambert, J.-C.; Grenier-Boley, B.; Bellenguez, C.; Pasquier, F.; Campion, D.; Dartigues, J.-F.; Berr, C.; Tzourio, C.; Amouyel, P. PLD3 and sporadic Alzheimer's disease risk. Nature 2015, 520, E1. [CrossRef]

108. van der Lee, S.J.; Holstege, H.; Wong, T.H.; Jakobsdottir, J.; Bis, J.C.; Chouraki, V.; van Rooij, J.G.J.; Grove, M.L.; Smith, A.V.; Amin, N.; et al. PLD3 variants in population studies. Nature 2015, 520, E2-E3. [CrossRef]

109. Heilmann, S.; Drichel, D.; Clarimon, J.; Fernández, V.; Lacour, A.; Wagner, H.; Thelen, M.; Hernández, I.; Fortea, J.; Alegret, M.; et al. PLD3 in non-familial Alzheimer's disease. Nature 2015, 520, E3-E5. [CrossRef]

110. Fazzari, P.; Horre, K.; Arranz, A.M.; Frigerio, C.S.; Saito, T.; Saido, T.C.; De Strooper, B. PLD3 gene and processing of APP. Nature 2017, 541, E1-E2. [CrossRef]

111. Zhang, D.-F.; Fan, Y.; Wang, D.; Bi, R.; Zhang, C.; Fang, Y.; Yao, Y.-G. PLD3 in Alzheimer's Disease: A Modest Effect as Revealed by Updated Association and Expression Analyses. Mol. Neurobiol. 2016, 53, 4034-4045. [CrossRef]

112. Roginski, R.S.; Lau, C.W.; Santoiemma, P.P.; Weaver, S.J.; Du, P.; Soteropoulos, P.; Yang, J. The human GCOM1 complex gene interacts with the NMDA receptor and internexin-alpha. Gene 2018, 648, 42-53. [CrossRef]

113. Roginski, R.S.; Goubaeva, F.; Mikami, M.; Fried-Cassorla, E.; Nair, M.R.; Yang, J. GRINL1A colocalizes with $\mathrm{N}$-methyl D-aspartate receptor NR1 subunit and reduces N-methyl D-aspartate toxicity. Neuroreport 2008, 19, 1721-1726. [CrossRef]

114. Wong, M.Y.; Liu, C.; Wang, S.S.H.; Roquas, A.C.F.; Fowler, S.C.; Kaeser, P.S. Liprin- $\alpha 3$ controls vesicle docking and exocytosis at the active zone of hippocampal synapses. Proc. Natl. Acad. Sci. USA 2018, 115, 2234-2239. [CrossRef] [PubMed]

115. Bruschetta, G.; Jin, S.; Kim, J.D.; Diano, S. Prolyl carboxypeptidase in Agouti-related Peptide neurons modulates food intake and body weight. Mol. Metab. 2018, 10, 28-38. [CrossRef]

116. Sakagami, H.; Kamata, A.; Fukunaga, K.; Kondo, H. Functional assay of EFA6A, a guanine nucleotide exchange factor for ADP-ribosylation factor 6 (ARF6), in dendritic formation of hippocampal neurons. Meth. Enzymol. 2005, 404, 232-242.

117. Choi, S.; Ko, J.; Lee, J.-R.; Lee, H.W.; Kim, K.; Chung, H.S.; Kim, H.; Kim, E. ARF6 and EFA6A regulate the development and maintenance of dendritic spines. J. Neurosci. 2006, 26, 4811-4819. [CrossRef]

118. Fukaya, M.; Fukushima, D.; Hara, Y.; Sakagami, H. EFA6A, a guanine nucleotide exchange factor for Arf6, interacts with sorting nexin-1 and regulates neurite outgrowth. J. Neurochem. 2014, 129, 21-36. [CrossRef]

119. Sironi, C.; Teesalu, T.; Muggia, A.; Fontana, G.; Marino, F.; Savaresi, S.; Talarico, D. EFA6A encodes two isoforms with distinct biological activities in neuronal cells. J. Cell. Sci. 2009, 122, 2108-2118. [CrossRef]

120. Sakagami, H. The EFA6 family: Guanine nucleotide exchange factors for ADP ribosylation factor 6 at neuronal synapses. Tohoku J. Exp. Med. 2008, 214, 191-198. [CrossRef]

121. Dong, H.; Zhu, M.; Meng, L.; Ding, Y.; Yang, D.; Zhang, S.; Qiang, W.; Fisher, D.W.; Xu, E.Y. Pumilio2 regulates synaptic plasticity via translational repression of synaptic receptors in mice. Oncotarget 2018, 9, 32134-32148. [CrossRef]

122. Siemen, H.; Colas, D.; Heller, H.C.; Brüstle, O.; Pera, R.A.R. Pumilio-2 function in the mouse nervous system. PLOS ONE 2011, 6, e25932. [CrossRef]

123. Vessey, J.P.; Schoderboeck, L.; Gingl, E.; Luzi, E.; Riefler, J.; Di Leva, F.; Karra, D.; Thomas, S.; Kiebler, M.A.; Macchi, P. Mammalian Pumilio 2 regulates dendrite morphogenesis and synaptic function. Proc. Natl. Acad. Sci. USA 2010, 107, 3222-3227. [CrossRef]

124. Marrero, E.; Rossi, S.G.; Darr, A.; Tsoulfas, P.; Rotundo, R.L. Translational regulation of acetylcholinesterase by the RNA-binding protein Pumilio-2 at the neuromuscular synapse. J. Biol. Chem. 2011, 286, 36492-36499. [CrossRef] 
125. Follwaczny, P.; Schieweck, R.; Riedemann, T.; Demleitner, A.; Straub, T.; Klemm, A.H.; Bilban, M.; Sutor, B.; Popper, B.; Kiebler, M.A. Pumilio2-deficient mice show a predisposition for epilepsy. Dis. Model Mech. 2017, 10, 1333-1342. [CrossRef]

126. Zhang, M.; Chen, D.; Xia, J.; Han, W.; Cui, X.; Neuenkirchen, N.; Hermes, G.; Sestan, N.; Lin, H. Post-transcriptional regulation of mouse neurogenesis by Pumilio proteins. Genes Dev. 2017, 31, 1354-1369. [CrossRef] [PubMed]

127. Wu, X.-L.; Huang, H.; Huang, Y.-Y.; Yuan, J.-X.; Zhou, X.; Chen, Y.-M. Reduced Pumilio-2 expression in patients with temporal lobe epilepsy and in the lithium-pilocarpine induced epilepsy rat model. Epilepsy Behav. 2015, 50, 31-39. [CrossRef]

128. Driscoll, H.E.; Muraro, N.I.; He, M.; Baines, R.A. Pumilio-2 regulates translation of Nav1.6 to mediate homeostasis of membrane excitability. J. Neurosci. 2013, 33, 9644-9654. [CrossRef]

129. Vessey, J.P.; Vaccani, A.; Xie, Y.; Dahm, R.; Karra, D.; Kiebler, M.A.; Macchi, P. Dendritic localization of the translational repressor Pumilio 2 and its contribution to dendritic stress granules. J. Neurosci. 2006, 26, 6496-6508. [CrossRef]

130. Muto, A.; Arai, K.-I.; Watanabe, S. Rab11-FIP4 is predominantly expressed in neural tissues and involved in proliferation as well as in differentiation during zebrafish retinal development. Dev. Biol. 2006, 292, 90-102. [CrossRef]

131. Nishimura, N.; Van Huyen Pham, T.; Hartomo, T.B.; Lee, M.J.; Hasegawa, D.; Takeda, H.; Kawasaki, K.; Kosaka, Y.; Yamamoto, T.; Morikawa, S.; et al. Rab15 expression correlates with retinoic acid-induced differentiation of neuroblastoma cells. Oncol. Rep. 2011, 26, 145-151. [CrossRef] [PubMed]

132. Hao, H.; Veleri, S.; Sun, B.; Kim, D.S.; Keeley, P.W.; Kim, J.-W.; Yang, H.-J.; Yadav, S.P.; Manjunath, S.H.; Sood, R.; et al. Regulation of a novel isoform of Receptor Expression Enhancing Protein REEP6 in rod photoreceptors by bZIP transcription factor NRL. Hum. Mol. Genet. 2014, 23, 4260-4271. [CrossRef] [PubMed]

133. Agrawal, S.A.; Burgoyne, T.; Eblimit, A.; Bellingham, J.; Parfitt, D.A.; Lane, A.; Nichols, R.; Asomugha, C.; Hayes, M.J.; Munro, P.M.; et al. REEP6 deficiency leads to retinal degeneration through disruption of ER homeostasis and protein trafficking. Hum. Mol. Genet. 2017, 26, 2667-2677. [CrossRef] [PubMed]

134. Veleri, S.; Nellissery, J.; Mishra, B.; Manjunath, S.H.; Brooks, M.J.; Dong, L.; Nagashima, K.; Qian, H.; Gao, C.; Sergeev, Y.V.; et al. REEP6 mediates trafficking of a subset of Clathrin-coated vesicles and is critical for rod photoreceptor function and survival. Hum. Mol. Genet. 2017, 26, 2218-2230. [CrossRef]

135. Arno, G.; Agrawal, S.A.; Eblimit, A.; Bellingham, J.; Xu, M.; Wang, F.; Chakarova, C.; Parfitt, D.A.; Lane, A.; Burgoyne, T.; et al. Mutations in REEP6 Cause Autosomal-Recessive Retinitis Pigmentosa. Am. J. Hum. Genet. 2016, 99, 1305-1315. [CrossRef] [PubMed]

136. Dinamarca, M.C.; Guzzetti, F.; Karpova, A.; Lim, D.; Mitro, N.; Musardo, S.; Mellone, M.; Marcello, E.; Stanic, J.; Samaddar, T.; et al. Ring finger protein 10 is a novel synaptonuclear messenger encoding activation of NMDA receptors in hippocampus. Elife 2016, 5, e12430. [CrossRef]

137. Carrano, N.; Samaddar, T.; Brunialti, E.; Franchini, L.; Marcello, E.; Ciana, P.; Mauceri, D.; Di Luca, M.; Gardoni, F. The Synaptonuclear Messenger RNF10 Acts as an Architect of Neuronal Morphology. Mol. Neurobiol. 2019, 56, 7583-7593. [CrossRef]

138. Mateu-Huertas, E.; Rodriguez-Revenga, L.; Alvarez-Mora, M.I.; Madrigal, I.; Willemsen, R.; Milà, M.; Martí, E.; Estivill, X. Blood expression profiles of fragile X premutation carriers identify candidate genes involved in neurodegenerative and infertility phenotypes. Neurobiol. Dis. 2014, 65, 43-54. [CrossRef]

139. Marcello, E.; Di Luca, M.; Gardoni, F. Synapse-to-nucleus communication: From developmental disorders to Alzheimer's disease. Curr. Opin. Neurobiol. 2018, 48, 160-166. [CrossRef]

140. Malik, Y.S.; Sheikh, M.A.; Lai, M.; Cao, R.; Zhu, X. RING finger protein 10 regulates retinoic acid-induced neuronal differentiation and the cell cycle exit of P19 embryonic carcinoma cells. J. Cell. Biochem. 2013, 114, 2007-2015. [CrossRef]

141. Hoshikawa, S.; Ogata, T.; Fujiwara, S.; Nakamura, K.; Tanaka, S. A novel function of RING finger protein 10 in transcriptional regulation of the myelin-associated glycoprotein gene and myelin formation in Schwann cells. PLoS ONE 2008, 3, e3464. [CrossRef] [PubMed] 
142. Klauck, S.M.; Felder, B.; Kolb-Kokocinski, A.; Schuster, C.; Chiocchetti, A.; Schupp, I.; Wellenreuther, R.; Schmötzer, G.; Poustka, F.; Breitenbach-Koller, L.; et al. Mutations in the ribosomal protein gene RPL10 suggest a novel modulating disease mechanism for autism. Mol. Psychiatry 2006, 11, 1073-1084. [CrossRef] [PubMed]

143. Gong, X.; Delorme, R.; Fauchereau, F.; Durand, C.M.; Chaste, P.; Betancur, C.; Goubran-Botros, H.; Nygren, G.; Anckarsäter, H.; Rastam, M.; et al. An investigation of ribosomal protein L10 gene in autism spectrum disorders. BMC Med. Genet. 2009, 10, 7. [CrossRef]

144. Chiocchetti, A.G.; Haslinger, D.; Boesch, M.; Karl, T.; Wiemann, S.; Freitag, C.M.; Poustka, F.; Scheibe, B.; Bauer, J.W.; Hintner, H.; et al. Protein signatures of oxidative stress response in a patient specific cell line model for autism. Mol. Autism 2014, 5, 10. [CrossRef] [PubMed]

145. Zanni, G.; Kalscheuer, V.M.; Friedrich, A.; Barresi, S.; Alfieri, P.; Di Capua, M.; Haas, S.A.; Piccini, G.; Karl, T.; Klauck, S.M.; et al. A Novel Mutation in RPL10 (Ribosomal Protein L10) Causes X-Linked Intellectual Disability, Cerebellar Hypoplasia, and Spondylo-Epiphyseal Dysplasia. Hum. Mutat. 2015, 36, 1155-1158. [CrossRef] [PubMed]

146. Vandewalle, J.; Van Esch, H.; Govaerts, K.; Verbeeck, J.; Zweier, C.; Madrigal, I.; Mila, M.; Pijkels, E.; Fernandez, I.; Kohlhase, J.; et al. Dosage-dependent severity of the phenotype in patients with mental retardation due to a recurrent copy-number gain at Xq28 mediated by an unusual recombination. Am. J. Hum. Genet. 2009, 85, 809-822. [CrossRef] [PubMed]

147. Brooks, S.S.; Wall, A.L.; Golzio, C.; Reid, D.W.; Kondyles, A.; Willer, J.R.; Botti, C.; Nicchitta, C.V.; Katsanis, N.; Davis, E.E. A novel ribosomopathy caused by dysfunction of RPL10 disrupts neurodevelopment and causes X-linked microcephaly in humans. Genetics 2014, 198, 723-733. [CrossRef]

148. Kalendar, R.; Belyayev, A.; Zachepilo, T.; Vaido, A.; Maidanyuk, D.; Schulman, A.H.; Dyuzhikova, N. Copy-number variation of housekeeping gene rpl13a in rat strains selected for nervous system excitability. Mol. Cell. Probes 2017, 33, 11-15. [CrossRef]

149. Perucho, L.; Artero-Castro, A.; Guerrero, S.; Ramón y Cajal, S.; LLeonart, M.E.; Wang, Z.-Q. RPLP1, a crucial ribosomal protein for embryonic development of the nervous system. PLoS ONE 2014, 9, e99956. [CrossRef]

150. Evans, H.T.; Benetatos, J.; van Roijen, M.; Bodea, L.-G.; Götz, J. Decreased synthesis of ribosomal proteins in tauopathy revealed by non-canonical amino acid labelling. EMBO J. 2019, 38, e101174. [CrossRef]

151. Miyata, S.; Mori, Y.; Tohyama, M. PRMT3 is essential for dendritic spine maturation in rat hippocampal neurons. Brain Res. 2010, 1352, 11-20. [CrossRef] [PubMed]

152. Grupe, A.; Li, Y.; Rowland, C.; Nowotny, P.; Hinrichs, A.L.; Smemo, S.; Kauwe, J.S.K.; Maxwell, T.J.; Cherny, S.; Doil, L.; et al. A scan of chromosome 10 identifies a novel locus showing strong association with late-onset Alzheimer disease. Am. J. Hum. Genet. 2006, 78, 78-88. [CrossRef]

153. Kalathur, R.K.R.; Giner-Lamia, J.; Machado, S.; Barata, T.; Ayasolla, K.R.S.; Futschik, M.E. The unfolded protein response and its potential role in Huntington's disease elucidated by a systems biology approach. F1000Res 2015, 4, 103. [CrossRef] [PubMed]

154. De Graeve, S.; Marinelli, S.; Stolz, F.; Hendrix, J.; Vandamme, J.; Engelborghs, Y.; Van Dijck, P.; Thevelein, J.M. Mammalian ribosomal and chaperone protein RPS3A counteracts $\alpha$-synuclein aggregation and toxicity in a yeast model system. Biochem. J. 2013, 455, 295-306. [CrossRef] [PubMed]

155. Watkins-Chow, D.E.; Cooke, J.; Pidsley, R.; Edwards, A.; Slotkin, R.; Leeds, K.E.; Mullen, R.; Baxter, L.L.; Campbell, T.G.; Salzer, M.C.; et al. Mutation of the diamond-blackfan anemia gene Rps7 in mouse results in morphological and neuroanatomical phenotypes. PLoS Genet. 2013, 9, e1003094. [CrossRef]

156. Gong, X.; Wang, H. SHANK1 and autism spectrum disorders. Sci. China Life Sci. 2015, 58, 985-990. [CrossRef]

157. Monteiro, P.; Feng, G. SHANK proteins: Roles at the synapse and in autism spectrum disorder. Nat. Rev. Neurosci. 2017, 18, 147-157. [CrossRef]

158. Guilmatre, A.; Huguet, G.; Delorme, R.; Bourgeron, T. The emerging role of SHANK genes in neuropsychiatric disorders. Dev. Neurobiol. 2014, 74, 113-122. [CrossRef]

159. Sungur, A.Ö.; Schwarting, R.K.W.; Wöhr, M. Behavioral phenotypes and neurobiological mechanisms in the Shank1 mouse model for autism spectrum disorder: A translational perspective. Behav. Brain Res. 2018, 352, 46-61. [CrossRef]

160. Jiang, Y.-H.; Ehlers, M.D. Modeling autism by SHANK gene mutations in mice. Neuron 2013, 78, 8-27. [CrossRef] 
161. Wu, L.-X.; Sun, C.-K.; Zhang, Y.-M.; Fan, M.; Xu, J.; Ma, H.; Zhang, J. Involvement of the Snk-SPAR pathway in glutamate-induced excitotoxicity in cultured hippocampal neurons. Brain Res. 2007, 1168, 38-45. [CrossRef] [PubMed]

162. Pak, D.T.S.; Sheng, M. Targeted protein degradation and synapse remodeling by an inducible protein kinase. Science 2003, 302, 1368-1373. [CrossRef] [PubMed]

163. Meyer, G.; Brose, N. Neuroscience. SPARring with spines. Science 2003, 302, 1341-1344. [CrossRef] [PubMed]

164. Maruoka, H.; Konno, D.; Hori, K.; Sobue, K. Collaboration of PSD-Zip70 with its binding partner, SPAR, in dendritic spine maturity. J. Neurosci. 2005, 25, 1421-1430. [CrossRef]

165. Lu, X.-J.; Chen, X.-Q.; Weng, J.; Zhang, H.-Y.; Pak, D.T.; Luo, J.-H.; Du, J.-Z. Hippocampal spine-associated Rap-specific GTPase-activating protein induces enhancement of learning and memory in postnatally hypoxia-exposed mice. Neuroscience 2009, 162, 404-414. [CrossRef] [PubMed]

166. Seeburg, D.P.; Feliu-Mojer, M.; Gaiottino, J.; Pak, D.T.S.; Sheng, M. Critical role of CDK5 and Polo-like kinase 2 in homeostatic synaptic plasticity during elevated activity. Neuron 2008, 58, 571-583. [CrossRef] [PubMed]

167. Herrick, S.; Evers, D.M.; Lee, J.-Y.; Udagawa, N.; Pak, D.T.S. Postsynaptic PDLIM5/Enigma Homolog binds SPAR and causes dendritic spine shrinkage. Mol. Cell. Neurosci. 2010, 43, 188-200. [CrossRef]

168. Sui, H.; Lu, X.-G.; Zhan, L.-B.; Jiang, W.-Z.; Qi, X.; Gong, X.-Y.; Niu, X.-P. Decreased expression of spine-associated Rap guanosine triphosphatase-activating protein (SPAR) in glutamate-treated primary hippocampal neurons. J. Clin. Neurosci. 2010, 17, 1042-1046. [CrossRef]

169. Chen, Y.; Yuanxiang, P.; Knöpfel, T.; Thomas, U.; Behnisch, T. Hippocampal LTP triggers proteasome-mediated SPAR degradation in CA1 neurons. Synapse 2012, 66, 142-150. [CrossRef]

170. Mihalas, A.B.; Araki, Y.; Huganir, R.L.; Meffert, M.K. Opposing action of nuclear factor кB and Polo-like kinases determines a homeostatic end point for excitatory synaptic adaptation. J. Neurosci. 2013, 33, 16490-16501. [CrossRef]

171. Ang, X.L.; Seeburg, D.P.; Sheng, M.; Harper, J.W. Regulation of postsynaptic RapGAP SPAR by Polo-like kinase 2 and the SCFbeta-TRCP ubiquitin ligase in hippocampal neurons. J. Biol. Chem. 2008, 283, 29424-29432. [CrossRef]

172. Gong, X.; Lu, X.; Zhan, L.; Sui, H.; Qi, X.; Ji, Z.; Niu, X.; Liu, L. Role of the SNK-SPAR pathway in the development of Alzheimer's disease. IUBMB Life 2010, 62, 214-221. [CrossRef]

173. Sui, H.; Zhan, L.; Niu, X.; Liang, L.; Li, X. The SNK and SPAR signaling pathway changes in hippocampal neurons treated with amyloid-beta peptide in vitro. Neuropeptides 2017, 63, 43-48. [CrossRef]

174. Al-Muhaizea, M.A.; AlMutairi, F.; Almass, R.; AlHarthi, S.; Aldosary, M.S.; Alsagob, M.; AlOdaib, A.; Colak, D.; Kaya, N. A Novel Homozygous Mutation in SPTBN2 Leads to Spinocerebellar Ataxia in a Consanguineous Family: Report of a New Infantile-Onset Case and Brief Review of the Literature. Cerebellum 2018, 17, 276-285. [CrossRef]

175. Mizuno, T.; Kashimada, A.; Nomura, T.; Moriyama, K.; Yokoyama, H.; Hasegawa, S.; Takagi, M.; Mizutani, S. Infantile-onset spinocerebellar ataxia type 5 associated with a novel SPTBN2 mutation: A case report. Brain Dev. 2019, 41, 630-633. [CrossRef]

176. Durr, A. Autosomal dominant cerebellar ataxias: Polyglutamine expansions and beyond. Lancet Neurol. 2010, 9, 885-894. [CrossRef]

177. Parolin Schnekenberg, R.; Perkins, E.M.; Miller, J.W.; Davies, W.I.L.; D'Adamo, M.C.; Pessia, M.; Fawcett, K.A.; Sims, D.; Gillard, E.; Hudspith, K.; et al. De novo point mutations in patients diagnosed with ataxic cerebral palsy. Brain 2015, 138, 1817-1832. [CrossRef]

178. Jacob, F.-D.; Ho, E.S.; Martinez-Ojeda, M.; Darras, B.T.; Khwaja, O.S. Case of infantile onset spinocerebellar ataxia type 5. J. Child Neurol. 2013, 28, 1292-1295. [CrossRef]

179. Ikeda, Y.; Dick, K.A.; Weatherspoon, M.R.; Gincel, D.; Armbrust, K.R.; Dalton, J.C.; Stevanin, G.; Dürr, A.; Zühlke, C.; Bürk, K.; et al. Spectrin mutations cause spinocerebellar ataxia type 5. Nat. Genet. 2006, 38, 184-190. [CrossRef]

180. Németh, A.H.; Kwasniewska, A.C.; Lise, S.; Parolin Schnekenberg, R.; Becker, E.B.E.; Bera, K.D.; Shanks, M.E.; Gregory, L.; Buck, D.; Zameel Cader, M.; et al. Next generation sequencing for molecular diagnosis of neurological disorders using ataxias as a model. Brain 2013, 136, 3106-3118. [CrossRef]

181. Armbrust, K.R.; Wang, X.; Hathorn, T.J.; Cramer, S.W.; Chen, G.; Zu, T.; Kangas, T.; Zink, A.N.; Öz, G.; Ebner, T.J.; et al. Mutant $\beta$-III spectrin causes mGluR1 $\alpha$ mislocalization and functional deficits in a mouse model of spinocerebellar ataxia type 5. J. Neurosci. 2014, 34, 9891-9904. [CrossRef] 
182. Perkins, E.M.; Clarkson, Y.L.; Sabatier, N.; Longhurst, D.M.; Millward, C.P.; Jack, J.; Toraiwa, J.; Watanabe, M.; Rothstein, J.D.; Lyndon, A.R.; et al. Loss of beta-III spectrin leads to Purkinje cell dysfunction recapitulating the behavior and neuropathology of spinocerebellar ataxia type 5 in humans. J. Neurosci. 2010, 30, 4857-4867. [CrossRef]

183. Lise, S.; Clarkson, Y.; Perkins, E.; Kwasniewska, A.; Sadighi Akha, E.; Schnekenberg, R.P.; Suminaite, D.; Hope, J.; Baker, I.; Gregory, L.; et al. Recessive mutations in SPTBN2 implicate $\beta$-III spectrin in both cognitive and motor development. PLoS Genet. 2012, 8, e1003074. [CrossRef]

184. Baltussen, L.L.; Rosianu, F.; Ultanir, S.K. Kinases in synaptic development and neurological diseases. Prog. Neuropsychopharmacol. Biol. Psychiatry 2018, 84, 343-352. [CrossRef]

185. Yadav, S.; Oses-Prieto, J.A.; Peters, C.J.; Zhou, J.; Pleasure, S.J.; Burlingame, A.L.; Jan, L.Y.; Jan, Y.-N. TAOK2 Kinase Mediates PSD95 Stability and Dendritic Spine Maturation through Septin7 Phosphorylation. Neuron 2017, 93, 379-393. [CrossRef]

186. Richter, M.; Murtaza, N.; Scharrenberg, R.; White, S.H.; Johanns, O.; Walker, S.; Yuen, R.K.C.; Schwanke, B.; Bedürftig, B.; Henis, M.; et al. Altered TAOK2 activity causes autism-related neurodevelopmental and cognitive abnormalities through RhoA signaling. Mol. Psychiatry 2019, 24, 1329-1350. [CrossRef]

187. Chen, J.; Yu, S.; Fu, Y.; Li, X. Synaptic proteins and receptors defects in autism spectrum disorders. Front. Cell. Neurosci. 2014, 8, 276. [CrossRef]

188. de Anda, F.C.; Rosario, A.L.; Durak, O.; Tran, T.; Gräff, J.; Meletis, K.; Rei, D.; Soda, T.; Madabhushi, R.; Ginty, D.D.; et al. Autism spectrum disorder susceptibility gene TAOK2 affects basal dendrite formation in the neocortex. Nat. Neurosci. 2012, 15, 1022-1031. [CrossRef]

189. Roque, C.G.; Wong, H.H.-W.; Lin, J.Q.; Holt, C.E. Tumor protein Tctp regulates axon development in the embryonic visual system. Development 2016, 143, 1134-1148. [CrossRef]

190. Filatova, E.V.; Shadrina, M.I.; Alieva, A.K.; Kolacheva, A.A.; Slominsky, P.A.; Ugrumov, M.V. Expression analysis of genes of ubiquitin-proteasome protein degradation system in MPTP-induced mice models of early stages of Parkinson's disease. Dokl. Biochem. Biophys. 2014, 456, 116-118. [CrossRef]

191. Vogl, A.M.; Brockmann, M.M.; Giusti, S.A.; Maccarrone, G.; Vercelli, C.A.; Bauder, C.A.; Richter, J.S.; Roselli, F.; Hafner, A.-S.; Dedic, N.; et al. Neddylation inhibition impairs spine development, destabilizes synapses and deteriorates cognition. Nat. Neurosci. 2015, 18, 239-251. [CrossRef]

192. Deng, G.; Jin, L. The effects of vasoactive intestinal peptide in neurodegenerative disorders. Neurol. Res. 2017, 39, 65-72. [CrossRef]

193. Fahrenkrug, J. Transmitter role of vasoactive intestinal peptide. Pharmacol. Toxicol. 1993, 72, 354-363. [CrossRef]

194. Hill, J.M. Vasoactive intestinal peptide in neurodevelopmental disorders: Therapeutic potential. Curr. Pharm. Des. 2007, 13, 1079-1089. [CrossRef]

195. Baßler, J.; Hurt, E. Eukaryotic Ribosome Assembly. Annu. Rev. Biochem. 2019, 88, 281-306. [CrossRef]

196. Knowles, R.B.; Sabry, J.H.; Martone, M.E.; Deerinck, T.J.; Ellisman, M.H.; Bassell, G.J.; Kosik, K.S. Translocation of RNA granules in living neurons. J. Neurosci. 1996, 16, 7812-7820. [CrossRef]

197. Mauro, V.P.; Edelman, G.M. The ribosome filter hypothesis. Proc. Natl. Acad. Sci. USA 2002, 99, 12031-12036. [CrossRef]

198. Sugihara, Y.; Honda, H.; Iida, T.; Morinaga, T.; Hino, S.; Okajima, T.; Matsuda, T.; Nadano, D. Proteomic analysis of rodent ribosomes revealed heterogeneity including ribosomal proteins L10-like, L22-like 1, and L39-like. J. Proteome Res. 2010, 9, 1351-1366. [CrossRef]

199. Shi, Z.; Fujii, K.; Kovary, K.M.; Genuth, N.R.; Röst, H.L.; Teruel, M.N.; Barna, M. Heterogeneous Ribosomes Preferentially Translate Distinct Subpools of mRNAs Genome-wide. Mol. Cell 2017, 67, 71-83.e7. [CrossRef]

200. Kraushar, M.L.; Viljetic, B.; Wijeratne, H.R.S.; Thompson, K.; Jiao, X.; Pike, J.W.; Medvedeva, V.; Groszer, M.; Kiledjian, M.; Hart, R.P.; et al. Thalamic WNT3 Secretion Spatiotemporally Regulates the Neocortical Ribosome Signature and mRNA Translation to Specify Neocortical Cell Subtypes. J. Neurosci. 2015, 35, 10911-10926. [CrossRef]

201. Kraushar, M.L.; Popovitchenko, T.; Volk, N.L.; Rasin, M.-R. The frontier of RNA metamorphosis and ribosome signature in neocortical development. Int. J. Dev. Neurosci. 2016, 55, 131-139. [CrossRef]

202. Komili, S.; Farny, N.G.; Roth, F.P.; Silver, P.A. Functional specificity among ribosomal proteins regulates gene expression. Cell 2007, 131, 557-571. [CrossRef]

203. Ulbrich, B.; Nierhaus, K.H. Pools of ribosomal proteins in Escherichia coli. Studies on the exchange of proteins between pools and ribosomes. Eur. J. Biochem. 1975, 57, 49-54. [CrossRef] 
204. Robertson, W.R.; Dowsett, S.J.; Hardy, S.J. Exchange of ribosomal proteins among the ribosomes of Escherichia coli. Mol. Gen. Genet. 1977, 157, 205-214. [CrossRef]

205. Subramanian, A.R.; van Duin, J. Exchange of individual ribosomal proteins between ribosomes as studied by heavy isotope-transfer experiments. Mol. Gen. Genet. 1977, 158, 1-9. [CrossRef]

206. Pulk, A.; Liiv, A.; Peil, L.; Maiväli, U.; Nierhaus, K.; Remme, J. Ribosome reactivation by replacement of damaged proteins. Mol. Microbiol. 2010, 75, 801-814. [CrossRef]

207. Dever, T.E.; Green, R. The elongation, termination, and recycling phases of translation in eukaryotes. Cold Spring Harb. Perspect. Biol. 2012, 4, a013706. [CrossRef]

208. Trimble, W.S.; Grinstein, S. Barriers to the free diffusion of proteins and lipids in the plasma membrane. J. Cell Biol. 2015, 208, 259-271. [CrossRef]

209. Lemmon, M.A. Membrane recognition by phospholipid-binding domains. Nat. Rev. Mol. Cell Biol. 2008, 9 , 99-111. [CrossRef]

210. Huber, K.M.; Gallagher, S.M.; Warren, S.T.; Bear, M.F. Altered synaptic plasticity in a mouse model of fragile X mental retardation. Proc. Natl. Acad. Sci. USA 2002, 99, 7746-7750. [CrossRef]

211. Hou, L.; Antion, M.D.; Hu, D.; Spencer, C.M.; Paylor, R.; Klann, E. Dynamic translational and proteasomal regulation of fragile $\mathrm{X}$ mental retardation protein controls mGluR-dependent long-term depression. Neuron 2006, 51, 441-454. [CrossRef]

212. Michalon, A.; Sidorov, M.; Ballard, T.M.; Ozmen, L.; Spooren, W.; Wettstein, J.G.; Jaeschke, G.; Bear, M.F.; Lindemann, L. Chronic pharmacological mGlu5 inhibition corrects fragile $X$ in adult mice. Neuron 2012, 74, 49-56. [CrossRef]

213. Paradee, W.; Melikian, H.E.; Rasmussen, D.L.; Kenneson, A.; Conn, P.J.; Warren, S.T. Fragile X mouse: Strain effects of knockout phenotype and evidence suggesting deficient amygdala function. Neuroscience 1999, 94, 185-192. [CrossRef]

214. Ding, Q.; Sethna, F.; Wang, H. Behavioral analysis of male and female Fmr1 knockout mice on C57BL/6 background. Behav. Brain Res. 2014, 271, 72-78. [CrossRef]

215. Qin, M.; Kang, J.; Smith, C.B. Increased rates of cerebral glucose metabolism in a mouse model of fragile $X$ mental retardation. Proc. Natl. Acad. Sci. USA 2002, 99, 15758-15763. [CrossRef]

216. Uutela, M.; Lindholm, J.; Louhivuori, V.; Wei, H.; Louhivuori, L.M.; Pertovaara, A.; Akerman, K.; Castrén, E.; Castrén, M.L. Reduction of BDNF expression in Fmr1 knockout mice worsens cognitive deficits but improves hyperactivity and sensorimotor deficits. Genes Brain Behav. 2012, 11, 513-523. [CrossRef]

217. Baker, K.B.; Wray, S.P.; Ritter, R.; Mason, S.; Lanthorn, T.H.; Savelieva, K.V. Male and female Fmr1 knockout mice on C57 albino background exhibit spatial learning and memory impairments. Genes Brain Behav. 2010, 9,562-574. [CrossRef]

218. Kooy, R.F.; D’Hooge, R.; Reyniers, E.; Bakker, C.E.; Nagels, G.; De Boulle, K.; Storm, K.; Clincke, G.; De Deyn, P.P.; Oostra, B.A.; et al. Transgenic mouse model for the fragile X syndrome. Am. J. Med. Genet. 1996, 64, 241-245. [CrossRef]

219. D’Hooge, R.; Nagels, G.; Franck, F.; Bakker, C.E.; Reyniers, E.; Storm, K.; Kooy, R.F.; Oostra, B.A.; Willems, P.J.; De Deyn, P.P. Mildly impaired water maze performance in male Fmr1 knockout mice. Neuroscience 1997, 76, 367-376. [CrossRef]

220. The Dutch-Belgian Fragile X Consortium. Fmr1 knockout mice: A model to study fragile X mental retardation. Cell 1994, 78, 23-33.

221. Shiina, N.; Yamaguchi, K.; Tokunaga, M. RNG105 deficiency impairs the dendritic localization of mRNAs for $\mathrm{Na}+\mathrm{K}+$ ATPase subunit isoforms and leads to the degeneration of neuronal networks. J. Neurosci. 2010, 30, 12816-12830. [CrossRef] [PubMed]

222. Ohashi, R.; Takao, K.; Miyakawa, T.; Shiina, N. Comprehensive behavioral analysis of RNG105 (Caprin1) heterozygous mice: Reduced social interaction and attenuated response to novelty. Sci. Rep. 2016, 6, 20775. [CrossRef] [PubMed]

223. Kedersha, N.; Panas, M.D.; Achorn, C.A.; Lyons, S.; Tisdale, S.; Hickman, T.; Thomas, M.; Lieberman, J.; McInerney, G.M.; Ivanov, P.; et al. G3BP-Caprin1-USP10 complexes mediate stress granule condensation and associate with $40 \mathrm{~S}$ subunits. J. Cell Biol. 2016, 212, 845-860. [CrossRef] [PubMed]

224. Tourrière,H.; Chebli, K.; Zekri, L.; Courselaud, B.; Blanchard, J.M.; Bertrand, E.; Tazi, J. The RasGAP-associated endoribonuclease G3BP assembles stress granules. J. Cell Biol. 2003, 160, 823-831. [CrossRef] 
225. Martin, S.; Zekri, L.; Metz, A.; Maurice, T.; Chebli, K.; Vignes, M.; Tazi, J. Deficiency of G3BP1, the stress granules assembly factor, results in abnormal synaptic plasticity and calcium homeostasis in neurons. J. Neurochem. 2013, 125, 175-184. [CrossRef]

226. Richter, J.D. CPEB: A life in translation. Trends Biochem. Sci. 2007, 32, 279-285. [CrossRef]

227. Alarcon, J.M.; Hodgman, R.; Theis, M.; Huang, Y.-S.; Kandel, E.R.; Richter, J.D. Selective modulation of some forms of schaffer collateral-CA1 synaptic plasticity in mice with a disruption of the CPEB-1 gene. Learn. Mem. 2004, 11, 318-327. [CrossRef]

228. Berger-Sweeney, J.; Zearfoss, N.R.; Richter, J.D. Reduced extinction of hippocampal-dependent memories in CPEB knockout mice. Learn. Mem. 2006, 13, 4-7. [CrossRef]

229. Heraud-Farlow, J.E.; Kiebler, M.A. The multifunctional Staufen proteins: Conserved roles from neurogenesis to synaptic plasticity. Trends Neurosci. 2014, 37, 470-479. [CrossRef]

230. Lebeau, G.; Miller, L.C.; Tartas, M.; McAdam, R.; Laplante, I.; Badeaux, F.; DesGroseillers, L.; Sossin, W.S.; Lacaille, J.-C. Staufen 2 regulates mGluR long-term depression and Map1b mRNA distribution in hippocampal neurons. Learn. Mem. 2011, 18, 314-326. [CrossRef]

231. Vessey, J.P.; Macchi, P.; Stein, J.M.; Mikl, M.; Hawker, K.N.; Vogelsang, P.; Wieczorek, K.; Vendra, G.; Riefler, J.; Tübing, F.; et al. A loss of function allele for murine Staufen1 leads to impairment of dendritic Staufen1-RNP delivery and dendritic spine morphogenesis. Proc. Natl. Acad. Sci. USA 2008, 105, 16374-16379. [CrossRef] [PubMed]

232. Berger, S.M.; Fernández-Lamo, I.; Schönig, K.; Fernández Moya, S.M.; Ehses, J.; Schieweck, R.; Clementi, S.; Enkel, T.; Grothe, S.; von Bohlen Und Halbach, O.; et al. Forebrain-specific, conditional silencing of Staufen2 alters synaptic plasticity, learning, and memory in rats. Genome Biol. 2017, 18, 222. [CrossRef] [PubMed]

233. Popper, B.; Demleitner, A.; Bolivar, V.J.; Kusek, G.; Snyder-Keller, A.; Schieweck, R.; Temple, S.; Kiebler, M.A. Staufen2 deficiency leads to impaired response to novelty in mice. Neurobiol. Learn. Mem. 2018, 150, 107-115. [CrossRef] [PubMed]

234. Popova, V.V.; Kurshakova, M.M.; Kopytova, D.V. Methods to study the RNA-protein interactions. Mol. Biol. (Mosk.) 2015, 49, 472-481. [CrossRef]

235. Dasti, A.; Cid-Samper, F.; Bechara, E.; Tartaglia, G.G. RNA-centric approaches to study RNA-protein interactions in vitro and in silico. Methods 2019. [CrossRef] [PubMed]

236. Djordjevic, M. SELEX experiments: New prospects, applications and data analysis in inferring regulatory pathways. Biomol. Eng. 2007, 24, 179-189. [CrossRef]

237. Zimmermann, B.; Bilusic, I.; Lorenz, C.; Schroeder, R. Genomic SELEX: A discovery tool for genomic aptamers. Methods 2010, 52, 125-132. [CrossRef]

238. Darmostuk, M.; Rimpelova, S.; Gbelcova, H.; Ruml, T. Current approaches in SELEX: An update to aptamer selection technology. Biotechnol. Adv. 2015, 33, 1141-1161. [CrossRef]

239. Ule, J.; Jensen, K.; Mele, A.; Darnell, R.B. CLIP: A method for identifying protein-RNA interaction sites in living cells. Methods 2005, 37, 376-386. [CrossRef]

240. Milek, M.; Wyler, E.; Landthaler, M. Transcriptome-wide analysis of protein-RNA interactions using high-throughput sequencing. Semin. Cell Dev. Biol. 2012, 23, 206-212. [CrossRef]

241. Darnell, J.C.; Mele, A.; Hung, K.Y.S.; Darnell, R.B. Mapping of In Vivo RNA-Binding Sites by Ultraviolet (UV)-Cross-Linking Immunoprecipitation (CLIP). Cold Spring Harb. Protoc. 2018, 2018. [CrossRef] [PubMed]

242. Rio, D.C. Electrophoretic mobility shift assays for RNA-protein complexes. Cold Spring Harb. Protoc. 2014, 2014, 435-440. [CrossRef] [PubMed]

243. Daras, G.; Alatzas, A.; Tsitsekian, D.; Templalexis, D.; Rigas, S.; Hatzopoulos, P. Detection of RNA-protein interactions using a highly sensitive non-radioactive electrophoretic mobility shift assay. Electrophoresis 2019, 40, 1365-1371. [CrossRef] [PubMed]

244. Lee, E.K.; Kim, H.H.; Kuwano, Y.; Abdelmohsen, K.; Srikantan, S.; Subaran, S.S.; Gleichmann, M.; Mughal, M.R.; Martindale, J.L.; Yang, X.; et al. hnRNP C promotes APP translation by competing with FMRP for APP mRNA recruitment to P bodies. Nat. Struct. Mol. Biol. 2010, 17, 732-739. [CrossRef]

245. Zalfa, F.; Giorgi, M.; Primerano, B.; Moro, A.; Di Penta, A.; Reis, S.; Oostra, B.; Bagni, C. The fragile X syndrome protein FMRP associates with BC1 RNA and regulates the translation of specific mRNAs at synapses. Cell 2003, 112, 317-327. [CrossRef] 
246. Zalfa, F.; Adinolfi, S.; Napoli, I.; Kühn-Hölsken, E.; Urlaub, H.; Achsel, T.; Pastore, A.; Bagni, C. Fragile X mental retardation protein (FMRP) binds specifically to the brain cytoplasmic RNAs BC1/BC200 via a novel RNA-binding motif. J. Biol. Chem. 2005, 280, 33403-33410. [CrossRef]

247. Iacoangeli, A.; Rozhdestvensky, T.S.; Dolzhanskaya, N.; Tournier, B.; Schütt, J.; Brosius, J.; Denman, R.B.; Khandjian, E.W.; Kindler, S.; Tiedge, H. On BC1 RNA and the fragile X mental retardation protein. Proc. Natl. Acad. Sci. USA 2008, 105, 734-739. [CrossRef]

248. Louhivuori, V.; Vicario, A.; Uutela, M.; Rantamäki, T.; Louhivuori, L.M.; Castrén, E.; Tongiorgi, E.; Akerman, K.E.; Castrén, M.L. BDNF and TrkB in neuronal differentiation of Fmr1-knockout mouse. Neurobiol. Dis. 2011, 41, 469-480. [CrossRef]

249. Gray, E.E.; Murphy, J.G.; Liu, Y.; Trang, I.; Tabor, G.T.; Lin, L.; Hoffman, D.A. Disruption of GpI mGluR-Dependent Cav2.3 Translation in a Mouse Model of Fragile X Syndrome. J. Neurosci. 2019, 39, 7453-7464. [CrossRef]

250. Sudhakaran, I.P.; Hillebrand, J.; Dervan, A.; Das, S.; Holohan, E.E.; Hülsmeier, J.; Sarov, M.; Parker, R.; VijayRaghavan, K.; Ramaswami, M. FMRP and Ataxin-2 function together in long-term olfactory habituation and neuronal translational control. Proc. Natl. Acad. Sci. USA 2014, 111, E99-E108. [CrossRef]

251. Kao, D.-I.; Aldridge, G.M.; Weiler, I.J.; Greenough, W.T. Altered mRNA transport, docking, and protein translation in neurons lacking fragile X mental retardation protein. Proc. Natl. Acad. Sci. USA 2010, 107, 15601-15606. [CrossRef] [PubMed]

252. Daroles, L.; Gribaudo, S.; Doulazmi, M.; Scotto-Lomassese, S.; Dubacq, C.; Mandairon, N.; Greer, C.A.; Didier, A.; Trembleau, A.; Caillé, I. Fragile X Mental Retardation Protein and Dendritic Local Translation of the Alpha Subunit of the Calcium/Calmodulin-Dependent Kinase II Messenger RNA Are Required for the Structural Plasticity Underlying Olfactory Learning. Biol. Psychiatry 2016, 80, 149-159. [CrossRef] [PubMed]

253. Dictenberg, J.B.; Swanger, S.A.; Antar, L.N.; Singer, R.H.; Bassell, G.J. A direct role for FMRP in activity-dependent dendritic mRNA transport links filopodial-spine morphogenesis to fragile $\mathrm{X}$ syndrome. Dev. Cell 2008, 14, 926-939. [CrossRef] [PubMed]

254. Muddashetty, R.S.; Kelić, S.; Gross, C.; Xu, M.; Bassell, G.J. Dysregulated metabotropic glutamate receptor-dependent translation of AMPA receptor and postsynaptic density-95 mRNAs at synapses in a mouse model of fragile X syndrome. J. Neurosci. 2007, 27, 5338-5348. [CrossRef] [PubMed]

255. Feuge, J.; Scharkowski, F.; Michaelsen-Preusse, K.; Korte, M. FMRP Modulates Activity-Dependent Spine Plasticity by Binding Cofilin1 mRNA and Regulating Localization and Local Translation. Cereb. Cortex 2019. [CrossRef]

256. Estes, P.S.; O'Shea, M.; Clasen, S.; Zarnescu, D.C. Fragile X protein controls the efficacy of mRNA transport in Drosophila neurons. Mol. Cell. Neurosci. 2008, 39, 170-179. [CrossRef]

257. Akins, M.R.; Berk-Rauch, H.E.; Kwan, K.Y.; Mitchell, M.E.; Shepard, K.A.; Korsak, L.I.T.; Stackpole, E.E.; Warner-Schmidt, J.L.; Sestan, N.; Cameron, H.A.; et al. Axonal ribosomes and mRNAs associate with fragile X granules in adult rodent and human brains. Hum. Mol. Genet. 2017, 26, 192-209. [CrossRef]

258. Miyashiro, K.Y.; Beckel-Mitchener, A.; Purk, T.P.; Becker, K.G.; Barret, T.; Liu, L.; Carbonetto, S.; Weiler, I.J.; Greenough, W.T.; Eberwine, J. RNA cargoes associating with FMRP reveal deficits in cellular functioning in Fmr1 null mice. Neuron 2003, 37, 417-431. [CrossRef]

259. Brown, V.; Small, K.; Lakkis, L.; Feng, Y.; Gunter, C.; Wilkinson, K.D.; Warren, S.T. Purified recombinant Fmrp exhibits selective RNA binding as an intrinsic property of the fragile $\mathrm{X}$ mental retardation protein. J. Biol. Chem. 1998, 273, 15521-15527. [CrossRef]

260. Antar, L.N.; Afroz, R.; Dictenberg, J.B.; Carroll, R.C.; Bassell, G.J. Metabotropic glutamate receptor activation regulates fragile $\mathrm{x}$ mental retardation protein and FMR1 mRNA localization differentially in dendrites and at synapses. J. Neurosci. 2004, 24, 2648-2655. [CrossRef]

261. Sabanov, V.; Braat, S.; D’Andrea, L.; Willemsen, R.; Zeidler, S.; Rooms, L.; Bagni, C.; Kooy, R.F.; Balschun, D. Impaired GABAergic inhibition in the hippocampus of Fmr1 knockout mice. Neuropharmacology 2017, 116, 71-81. [CrossRef]

262. Maurin, T.; Melko, M.; Abekhoukh, S.; Khalfallah, O.; Davidovic, L.; Jarjat, M.; D’Antoni, S.; Catania, M.V.; Moine, H.; Bechara, E.; et al. The FMRP/GRK4 mRNA interaction uncovers a new mode of binding of the Fragile X mental retardation protein in cerebellum. Nucleic Acids Res. 2015, 43, 8540-8550. [CrossRef]

263. Strumbos, J.G.; Brown, M.R.; Kronengold, J.; Polley, D.B.; Kaczmarek, L.K. Fragile X mental retardation protein is required for rapid experience-dependent regulation of the potassium channel Kv3.1b. J. Neurosci. 2010, 30, 10263-10271. [CrossRef] [PubMed] 
264. Gross, C.; Yao, X.; Pong, D.L.; Jeromin, A.; Bassell, G.J. Fragile X mental retardation protein regulates protein expression and mRNA translation of the potassium channel Kv4.2. J. Neurosci. 2011, 31, 5693-5698. [CrossRef] [PubMed]

265. Ceolin, L.; Bouquier, N.; Vitre-Boubaker, J.; Rialle, S.; Severac, D.; Valjent, E.; Perroy, J.; Puighermanal, E. Cell Type-Specific mRNA Dysregulation in Hippocampal CA1 Pyramidal Neurons of the Fragile X Syndrome Mouse Model. Front. Mol. Neurosci. 2017, 10, 340. [CrossRef] [PubMed]

266. Lu, R.; Wang, H.; Liang, Z.; Ku, L.; O'donnell, W.T.; Li, W.; Warren, S.T.; Feng, Y. The fragile X protein controls microtubule-associated protein $1 \mathrm{~B}$ translation and microtubule stability in brain neuron development. Proc. Natl. Acad. Sci. USA 2004, 101, 15201-15206. [CrossRef] [PubMed]

267. Wei, Z.-X.; Yi, Y.-H.; Sun, W.-W.; Wang, R.; Su, T.; Bai, Y.-J.; Liao, W.-P. Expression changes of microtubule associated protein 1B in the brain of Fmr1 knockout mice. Neurosci. Bull. 2007, 23, 203-208. [CrossRef] [PubMed]

268. Janusz, A.; Milek, J.; Perycz, M.; Pacini, L.; Bagni, C.; Kaczmarek, L.; Dziembowska, M. The Fragile X mental retardation protein regulates matrix metalloproteinase 9 mRNA at synapses. J. Neurosci. 2013, 33, 18234-18241. [CrossRef]

269. Jeon, S.J.; Kim, J.-W.; Kim, K.C.; Han, S.M.; Go, H.S.; Seo, J.E.; Choi, C.S.; Ryu, J.H.; Shin, C.Y.; Song, M.-R. Translational regulation of NeuroD1 expression by FMRP: Involvement in glutamatergic neuronal differentiation of cultured rat primary neural progenitor cells. Cell. Mol. Neurobiol. 2014, 34, 297-305. [CrossRef]

270. Chmielewska, J.J.; Kuzniewska, B.; Milek, J.; Urbanska, K.; Dziembowska, M. Neuroligin 1, 2, and 3 Regulation at the Synapse: FMRP-Dependent Translation and Activity-Induced Proteolytic Cleavage. Mol. Neurobiol. 2019, 56, 2741-2759. [CrossRef]

271. Kwan, K.Y.; Lam, M.M.S.; Johnson, M.B.; Dube, U.; Shim, S.; Rašin, M.-R.; Sousa, A.M.M.; Fertuzinhos, S.; Chen, J.-G.; Arellano, J.I.; et al. Species-dependent posttranscriptional regulation of NOS1 by FMRP in the developing cerebral cortex. Cell 2012, 149, 899-911. [CrossRef] [PubMed]

272. Zhang, M.; Wang, Q.; Huang, Y. Fragile X mental retardation protein FMRP and the RNA export factor NXF2 associate with and destabilize Nxf1 mRNA in neuronal cells. Proc. Natl. Acad. Sci. USA 2007, 104, 10057-10062. [CrossRef] [PubMed]

273. Maurin, T.; Lebrigand, K.; Castagnola, S.; Paquet, A.; Jarjat, M.; Popa, A.; Grossi, M.; Rage, F.; Bardoni, B. HITS-CLIP in various brain areas reveals new targets and new modalities of RNA binding by fragile $\mathrm{X}$ mental retardation protein. Nucleic Acids Res. 2018, 46, 6344-6355. [CrossRef] [PubMed]

274. Majumder, P.; Chu, J.-F.; Chatterjee, B.; Swamy, K.B.S.; Shen, C.-K.J. Co-regulation of mRNA translation by TDP-43 and Fragile X Syndrome protein FMRP. Acta Neuropathol. 2016, 132, 721-738. [CrossRef] [PubMed]

275. Tervonen, T.; Akerman, K.; Oostra, B.A.; Castrén, M. Rgs4 mRNA expression is decreased in the brain of Fmr1 knockout mouse. Brain Res. Mol. Brain Res. 2005, 133, 162-165. [CrossRef] [PubMed]

276. Bechara, E.G.; Didiot, M.C.; Melko, M.; Davidovic, L.; Bensaid, M.; Martin, P.; Castets, M.; Pognonec, P.; Khandjian, E.W.; Moine, H.; et al. A novel function for fragile $\mathrm{X}$ mental retardation protein in translational activation. PLoS Biol. 2009, 7, e16. [CrossRef]

277. Paul, A.; Nawalpuri, B.; Shah, D.; Sateesh, S.; Muddashetty, R.S.; Clement, J.P. Differential Regulation of Syngap1 Translation by FMRP Modulates eEF2 Mediated Response on NMDAR Activity. Front. Mol. Neurosci. 2019, 12, 97. [CrossRef]

278. Higashimori, H.; Morel, L.; Huth, J.; Lindemann, L.; Dulla, C.; Taylor, A.; Freeman, M.; Yang, Y. Astroglial FMRP-dependent translational down-regulation of mGluR5 underlies glutamate transporter GLT1 dysregulation in the fragile X mouse. Hum. Mol. Genet. 2013, 22, 2041-2054. [CrossRef]

279. Wang, H.; Ku, L.; Osterhout, D.J.; Li, W.; Ahmadian, A.; Liang, Z.; Feng, Y. Developmentally-programmed FMRP expression in oligodendrocytes: A potential role of FMRP in regulating translation in oligodendroglia progenitors. Hum. Mol. Genet. 2004, 13, 79-89. [CrossRef]

280. Rackham, O.; Brown, C.M. Visualization of RNA-protein interactions in living cells: FMRP and IMP1 interact on mRNAs. EMBO J. 2004, 23, 3346-3355. [CrossRef]

281. Fähling, M.; Mrowka, R.; Steege, A.; Kirschner, K.M.; Benko, E.; Förstera, B.; Persson, P.B.; Thiele, B.J.; Meier, J.C.; Scholz, H. Translational regulation of the human achaete-scute homologue- 1 by fragile $X$ mental retardation protein. J. Biol. Chem. 2009, 284, 4255-4266. [CrossRef] [PubMed] 
282. Hoeffer, C.A.; Sanchez, E.; Hagerman, R.J.; Mu, Y.; Nguyen, D.V.; Wong, H.; Whelan, A.M.; Zukin, R.S.; Klann, E.; Tassone, F. Altered mTOR signaling and enhanced CYFIP2 expression levels in subjects with fragile X syndrome. Genes Brain Behav. 2012, 11, 332-341. [CrossRef] [PubMed]

283. Sung, Y.J.; Dolzhanskaya, N.; Nolin, S.L.; Brown, T.; Currie, J.R.; Denman, R.B. The fragile X mental retardation protein FMRP binds elongation factor 1A mRNA and negatively regulates its translation in vivo. J. Biol. Chem. 2003, 278, 15669-15678. [CrossRef] [PubMed]

284. Li, Z.; Zhang, Y.; Ku, L.; Wilkinson, K.D.; Warren, S.T.; Feng, Y. The fragile X mental retardation protein inhibits translation via interacting with mRNA. Nucleic Acids Res. 2001, 29, 2276-2283. [CrossRef]

285. Castets, M.; Schaeffer, C.; Bechara, E.; Schenck, A.; Khandjian, E.W.; Luche, S.; Moine, H.; Rabilloud, T.; Mandel, J.-L.; Bardoni, B. FMRP interferes with the Rac1 pathway and controls actin cytoskeleton dynamics in murine fibroblasts. Hum. Mol. Genet. 2005, 14, 835-844. [CrossRef]

286. Chen, L.; Yun, S.W.; Seto, J.; Liu, W.; Toth, M. The fragile X mental retardation protein binds and regulates a novel class of mRNAs containing U rich target sequences. Neuroscience 2003, 120, 1005-1017. [CrossRef]

287. Ascano, M.; Mukherjee, N.; Bandaru, P.; Miller, J.B.; Nusbaum, J.D.; Corcoran, D.L.; Langlois, C.; Munschauer, M.; Dewell, S.; Hafner, M.; et al. FMRP targets distinct mRNA sequence elements to regulate protein expression. Nature 2012, 492, 382-386. [CrossRef]

288. Darnell, J.C.; Van Driesche, S.J.; Zhang, C.; Hung, K.Y.S.; Mele, A.; Fraser, C.E.; Stone, E.F.; Chen, C.; Fak, J.J.; Chi, S.W.; et al. FMRP stalls ribosomal translocation on mRNAs linked to synaptic function and autism. Cell 2011, 146, 247-261. [CrossRef]

289. Brown, V.; Jin, P.; Ceman, S.; Darnell, J.C.; O’Donnell, W.T.; Tenenbaum, S.A.; Jin, X.; Feng, Y.; Wilkinson, K.D.; Keene, J.D.; et al. Microarray identification of FMRP-associated brain mRNAs and altered mRNA translational profiles in fragile $\mathrm{X}$ syndrome. Cell 2001, 107, 477-487. [CrossRef]

290. Das Sharma, S.; Metz, J.B.; Li, H.; Hobson, B.D.; Hornstein, N.; Sulzer, D.; Tang, G.; Sims, P.A. Widespread Alterations in Translation Elongation in the Brain of Juvenile Fmr1 Knockout Mice. Cell Rep. 2019, 26, 3313-3322.e5. [CrossRef]

291. Liu, B.; Li, Y.; Stackpole, E.E.; Novak, A.; Gao, Y.; Zhao, Y.; Zhao, X.; Richter, J.D. Regulatory discrimination of mRNAs by FMRP controls mouse adult neural stem cell differentiation. Proc. Natl. Acad. Sci. USA 2018, 115, E11397-E11405. [CrossRef] [PubMed]

292. Xu, S.; Poidevin, M.; Han, E.; Bi, J.; Jin, P. Circadian rhythm-dependent alterations of gene expression in Drosophila brain lacking fragile X mental retardation protein. PLoS ONE 2012, 7, e37937. [CrossRef] [PubMed]

293. Bittel, D.C.; Kibiryeva, N.; Butler, M.G. Whole genome microarray analysis of gene expression in subjects with fragile X syndrome. Genet. Med. 2007, 9, 464-472. [CrossRef]

294. Stefanovic, S.; DeMarco, B.A.; Underwood, A.; Williams, K.R.; Bassell, G.J.; Mihailescu, M.R. Fragile X mental retardation protein interactions with a $G$ quadruplex structure in the 3'-untranslated region of NR2B mRNA. Mol. Biosyst. 2015, 11, 3222-3230. [CrossRef] [PubMed]

295. Menon, L.; Mader, S.A.; Mihailescu, M.-R. Fragile X mental retardation protein interactions with the microtubule associated protein 1B RNA. RNA 2008, 14, 1644-1655. [CrossRef] [PubMed]

296. Menon, L.; Mihailescu, M.-R. Interactions of the G quartet forming semaphorin 3F RNA with the RGG box domain of the fragile X protein family. Nucleic Acids Res. 2007, 35, 5379-5392. [CrossRef] [PubMed]

297. Zhang, Y.; Gaetano, C.M.; Williams, K.R.; Bassell, G.J.; Mihailescu, M.R. FMRP interacts with G-quadruplex structures in the 3'-UTR of its dendritic target Shank1 mRNA. RNA Biol. 2014, 11, 1364-1374. [CrossRef]

298. McAninch, D.S.; Heinaman, A.M.; Lang, C.N.; Moss, K.R.; Bassell, G.J.; Rita Mihailescu, M.; Evans, T.L. Fragile $\mathrm{X}$ mental retardation protein recognizes a $\mathrm{G}$ quadruplex structure within the survival motor neuron domain containing 1 mRNA 5'-UTR. Mol. Biosyst. 2017, 13, 1448-1457. [CrossRef]

299. Darnell, J.C.; Jensen, K.B.; Jin, P.; Brown, V.; Warren, S.T.; Darnell, R.B. Fragile X mental retardation protein targets $G$ quartet mRNAs important for neuronal function. Cell 2001, 107, 489-499. [CrossRef]

300. Ramos, A.; Hollingworth, D.; Pastore, A. G-quartet-dependent recognition between the FMRP RGG box and RNA. RNA 2003, 9, 1198-1207. [CrossRef]

301. Suhl, J.A.; Chopra, P.; Anderson, B.R.; Bassell, G.J.; Warren, S.T. Analysis of FMRP mRNA target datasets reveals highly associated mRNAs mediated by G-quadruplex structures formed via clustered WGGA sequences. Hum. Mol. Genet. 2014, 23, 5479-5491. [CrossRef] [PubMed] 
302. Vasilyev, N.; Polonskaia, A.; Darnell, J.C.; Darnell, R.B.; Patel, D.J.; Serganov, A. Crystal structure reveals specific recognition of a G-quadruplex RNA by a $\beta$-turn in the RGG motif of FMRP. Proc. Natl. Acad. Sci. USA 2015, 112, E5391-E5400. [CrossRef] [PubMed]

303. Schaeffer, C.; Bardoni, B.; Mandel, J.L.; Ehresmann, B.; Ehresmann, C.; Moine, H. The fragile X mental retardation protein binds specifically to its mRNA via a purine quartet motif. EMBO J. 2001, 20, 4803-4813. [CrossRef] [PubMed]

304. Zhang, F.; Kang, Y.; Wang, M.; Li, Y.; Xu, T.; Yang, W.; Song, H.; Wu, H.; Shu, Q.; Jin, P. Fragile X mental retardation protein modulates the stability of its m6A-marked messenger RNA targets. Hum. Mol. Genet. 2018, 27, 3936-3950. [CrossRef]

305. McEvoy, M.; Cao, G.; Montero Llopis, P.; Kundel, M.; Jones, K.; Hofler, C.; Shin, C.; Wells, D.G. Cytoplasmic polyadenylation element binding protein 1-mediated mRNA translation in Purkinje neurons is required for cerebellar long-term depression and motor coordination. J. Neurosci. 2007, 27, 6400-6411. [CrossRef]

306. Oe, S.; Yoneda, Y. Cytoplasmic polyadenylation element-like sequences are involved in dendritic targeting of BDNF mRNA in hippocampal neurons. FEBS Lett. 2010, 584, 3424-3430. [CrossRef]

307. Kim, K.C.; Oh, W.J.; Ko, K.H.; Shin, C.Y.; Wells, D.G. Cyclin B1 expression regulated by cytoplasmic polyadenylation element binding protein in astrocytes. J. Neurosci. 2011, 31, 12118-12128. [CrossRef]

308. Kundel, M.; Jones, K.J.; Shin, C.Y.; Wells, D.G. Cytoplasmic polyadenylation element-binding protein regulates neurotrophin-3-dependent beta-catenin mRNA translation in developing hippocampal neurons. J. Neurosci. 2009, 29, 13630-13639. [CrossRef]

309. Alves-Sampaio, A.; Troca-Marín, J.A.; Montesinos, M.L. NMDA-mediated regulation of DSCAM dendritic local translation is lost in a mouse model of Down's syndrome. J. Neurosci. 2010, 30, 13537-13548. [CrossRef]

310. Gerstner, J.R.; Vanderheyden, W.M.; LaVaute, T.; Westmark, C.J.; Rouhana, L.; Pack, A.I.; Wickens, M.; Landry, C.F. Time of day regulates subcellular trafficking, tripartite synaptic localization, and polyadenylation of the astrocytic Fabp7 mRNA. J. Neurosci. 2012, 32, 1383-1394. [CrossRef]

311. Zearfoss, N.R.; Alarcon, J.M.; Trifilieff, P.; Kandel, E.; Richter, J.D. A molecular circuit composed of CPEB-1 and c-Jun controls growth hormone-mediated synaptic plasticity in the mouse hippocampus. J. Neurosci. 2008, 28, 8502-8509. [CrossRef] [PubMed]

312. Liu, J.; Hu, J.-Y.; Wu, F.; Schwartz, J.H.; Schacher, S. Two mRNA-binding proteins regulate the distribution of syntaxin mRNA in Aplysia sensory neurons. J. Neurosci. 2006, 26, 5204-5214. [CrossRef] [PubMed]

313. Kochanek, D.M.; Wells, D.G. CPEB1 regulates the expression of MTDH/AEG-1 and glioblastoma cell migration. Mol. Cancer Res. 2013, 11, 149-160. [CrossRef] [PubMed]

314. Bava, F.-A.; Eliscovich, C.; Ferreira, P.G.; Miñana, B.; Ben-Dov, C.; Guigó, R.; Valcárcel, J.; Méndez, R. CPEB1 coordinates alternative 3'-UTR formation with translational regulation. Nature 2013, 495, 121-125. [CrossRef]

315. Nishimura, Y.; Kano, K.; Naito, K. Porcine CPEB1 is involved in Cyclin B translation and meiotic resumption in porcine oocytes. Anim. Sci. J. 2010, 81, 444-452. [CrossRef]

316. Han, S.J.; Martins, J.P.S.; Yang, Y.; Kang, M.K.; Daldello, E.M.; Conti, M. The Translation of Cyclin B1 and B2 is Differentially Regulated during Mouse Oocyte Reentry into the Meiotic Cell Cycle. Sci. Rep. 2017, 7, 14077. [CrossRef]

317. Sousa Martins, J.P.; Liu, X.; Oke, A.; Arora, R.; Franciosi, F.; Viville, S.; Laird, D.J.; Fung, J.C.; Conti, M. DAZL and CPEB1 regulate mRNA translation synergistically during oocyte maturation. J. Cell. Sci. 2016, 129, 1271-1282. [CrossRef]

318. Nagaoka, K.; Fujii, K.; Zhang, H.; Usuda, K.; Watanabe, G.; Ivshina, M.; Richter, J.D. CPEB1 mediates epithelial-to-mesenchyme transition and breast cancer metastasis. Oncogene 2016, 35, 2893-2901. [CrossRef]

319. Galardi, S.; Petretich, M.; Pinna, G.; D'Amico, S.; Loreni, F.; Michienzi, A.; Groisman, I.; Ciafrè, S.A. CPEB1 restrains proliferation of Glioblastoma cells through the regulation of p27(Kip1) mRNA translation. Sci. Rep. 2016, 6, 25219. [CrossRef]

320. Jones, K.J.; Korb, E.; Kundel, M.A.; Kochanek, A.R.; Kabraji, S.; McEvoy, M.; Shin, C.Y.; Wells, D.G. CPEB1 regulates beta-catenin mRNA translation and cell migration in astrocytes. Glia 2008, 56, 1401-1413. [CrossRef]

321. Rutledge, C.E.; Lau, H.-T.; Mangan, H.; Hardy, L.L.; Sunnotel, O.; Guo, F.; MacNicol, A.M.; Walsh, C.P.; Lees-Murdock, D.J. Efficient translation of Dnmt1 requires cytoplasmic polyadenylation and Musashi binding elements. PLoS ONE 2014, 9, e88385. [CrossRef] [PubMed] 
322. Hägele, S.; Kühn, U.; Böning, M.; Katschinski, D.M. Cytoplasmic polyadenylation-element-binding protein (CPEB) 1 and 2 bind to the HIF-1alpha mRNA 3'-UTR and modulate HIF-1alpha protein expression. Biochem. J. 2009, 417, 235-246. [CrossRef] [PubMed]

323. Caldeira, J.; Simões-Correia, J.; Paredes, J.; Pinto, M.T.; Sousa, S.; Corso, G.; Marrelli, D.; Roviello, F.; Pereira, P.S.; Weil, D.; et al. CPEB1, a novel gene silenced in gastric cancer: A Drosophila approach. Gut 2012, 61, 1115-1123. [CrossRef] [PubMed]

324. Takahashi, K.; Yi, H.; Gu, J.; Ikegami, D.; Liu, S.; Iida, T.; Kashiwagi, Y.; Dong, C.; Kunisawa, T.; Hao, S. The mitochondrial calcium uniporter contributes to morphine tolerance through pCREB and CPEB1 in rat spinal cord dorsal horn. Br. J. Anaesth. 2019, 123, e226-e238. [CrossRef]

325. Xu, M.; Fang, S.; Song, J.; Chen, M.; Zhang, Q.; Weng, Q.; Fan, X.; Chen, W.; Wu, X.; Wu, F.; et al. CPEB1 mediates hepatocellular carcinoma cancer stemness and chemoresistance. Cell Death Dis. 2018, 9, 957. [CrossRef]

326. Shin, J.; Paek, K.Y.; Ivshina, M.; Stackpole, E.E.; Richter, J.D. Essential role for non-canonical poly(A) polymerase GLD4 in cytoplasmic polyadenylation and carbohydrate metabolism. Nucleic Acids Res. 2017, 45, 6793-6804. [CrossRef] [PubMed]

327. Tay, J.; Richter, J.D. Germ cell differentiation and synaptonemal complex formation are disrupted in CPEB knockout mice. Dev. Cell 2001, 1, 201-213. [CrossRef]

328. Nairismägi, M.-L.; Vislovukh, A.; Meng, Q.; Kratassiouk, G.; Beldiman, C.; Petretich, M.; Groisman, R.; Füchtbauer, E.-M.; Harel-Bellan, A.; Groisman, I. Translational control of TWIST1 expression in MCF-10A cell lines recapitulating breast cancer progression. Oncogene 2012, 31, 4960-4966. [CrossRef]

329. Yin, J.; Park, G.; Lee, J.E.; Park, J.Y.; Kim, T.-H.; Kim, Y.-J.; Lee, S.-H.; Yoo, H.; Kim, J.H.; Park, J.B. CPEB1 modulates differentiation of glioma stem cells via downregulation of HES1 and SIRT1 expression. Oncotarget 2014, 5, 6756-6769. [CrossRef]

330. Alexandrov, I.M.; Ivshina, M.; Jung, D.Y.; Friedline, R.; Ko, H.J.; Xu, M.; O'Sullivan-Murphy, B.; Bortell, R.; Huang, Y.-T.; Urano, F.; et al. Cytoplasmic polyadenylation element binding protein deficiency stimulates PTEN and Stat3 mRNA translation and induces hepatic insulin resistance. PLoS Genet. 2012, 8, e1002457. [CrossRef]

331. Zhang, J.-H.; Panicker, L.M.; Seigneur, E.M.; Lin, L.; House, C.D.; Morgan, W.; Chen, W.C.; Mehta, H.; Haj-Ali, M.; Yu, Z.-X.; et al. Cytoplasmic polyadenylation element binding protein is a conserved target of tumor suppressor HRPT2/CDC73. Cell Death Differ. 2010, 17, 1551-1565. [CrossRef] [PubMed]

332. Udagawa, T.; Farny, N.G.; Jakovcevski, M.; Kaphzan, H.; Alarcon, J.M.; Anilkumar, S.; Ivshina, M.; Hurt, J.A.; Nagaoka, K.; Nalavadi, V.C.; et al. Genetic and acute CPEB1 depletion ameliorate fragile X pathophysiology. Nat. Med. 2013, 19, 1473-1477. [CrossRef] [PubMed]

333. Charlesworth, A.; Meijer, H.A.; de Moor, C.H. Specificity factors in cytoplasmic polyadenylation. Wiley Interdiscip. Rev. RNA 2013, 4, 437-461. [CrossRef] [PubMed]

334. Stepien, B.K.; Oppitz, C.; Gerlach, D.; Dag, U.; Novatchkova, M.; Krüttner, S.; Stark, A.; Keleman, K. RNA-binding profiles of Drosophila CPEB proteins Orb and Orb2. Proc. Natl. Acad. Sci. USA 2016, 113, E7030-E7038. [CrossRef] [PubMed]

335. Antar, L.N.; Dictenberg, J.B.; Plociniak, M.; Afroz, R.; Bassell, G.J. Localization of FMRP-associated mRNA granules and requirement of microtubules for activity-dependent trafficking in hippocampal neurons. Genes Brain Behav. 2005, 4, 350-359. [CrossRef] [PubMed]

336. El Fatimy, R.; Davidovic, L.; Tremblay, S.; Jaglin, X.; Dury, A.; Robert, C.; De Koninck, P.; Khandjian, E.W. Tracking the Fragile X Mental Retardation Protein in a Highly Ordered Neuronal RiboNucleoParticles Population: A Link between Stalled Polyribosomes and RNA Granules. PLoS Genet. 2016, 12, e1006192. [CrossRef] [PubMed]

337. Wu, L.; Wells, D.; Tay, J.; Mendis, D.; Abbott, M.A.; Barnitt, A.; Quinlan, E.; Heynen, A.; Fallon, J.R.; Richter, J.D. CPEB-mediated cytoplasmic polyadenylation and the regulation of experience-dependent translation of alpha-CaMKII mRNA at synapses. Neuron 1998, 21, 1129-1139. [CrossRef]

338. Huang, Y.-S.; Jung, M.-Y.; Sarkissian, M.; Richter, J.D. N-methyl-D-aspartate receptor signaling results in Aurora kinase-catalyzed CPEB phosphorylation and alpha CaMKII mRNA polyadenylation at synapses. EMBO J. 2002, 21, 2139-2148. [CrossRef]

339. Shiina, N.; Shinkura, K.; Tokunaga, M. A novel RNA-binding protein in neuronal RNA granules: Regulatory machinery for local translation. J. Neurosci. 2005, 25, 4420-4434. [CrossRef] 
340. Solomon, S.; Xu, Y.; Wang, B.; David, M.D.; Schubert, P.; Kennedy, D.; Schrader, J.W. Distinct structural features of caprin-1 mediate its interaction with G3BP-1 and its induction of phosphorylation of eukaryotic translation initiation factor 2alpha, entry to cytoplasmic stress granules, and selective interaction with a subset of mRNAs. Mol. Cell. Biol. 2007, 27, 2324-2342. [CrossRef]

341. Arguello, A.E.; DeLiberto, A.N.; Kleiner, R.E. RNA Chemical Proteomics Reveals the N6-Methyladenosine (m6A)-Regulated Protein-RNA Interactome. J. Am. Chem. Soc. 2017, 139, 17249-17252. [CrossRef] [PubMed]

342. Friedersdorf, M.B.; Keene, J.D. Advancing the functional utility of PAR-CLIP by quantifying background binding to mRNAs and lncRNAs. Genome Biol. 2014, 15, R2. [CrossRef] [PubMed]

343. Shiina, N. Liquid- and solid-like RNA granules form through specific scaffold proteins and combine into biphasic granules. J. Biol. Chem. 2019, 294, 3532-3548. [CrossRef]

344. Kim, Y.K.; Furic, L.; Desgroseillers, L.; Maquat, L.E. Mammalian Staufen1 recruits Upf1 to specific mRNA 3'UTRs so as to elicit mRNA decay. Cell 2005, 120, 195-208. [CrossRef] [PubMed]

345. Ferrandon, D.; Elphick, L.; Nüsslein-Volhard, C.; St Johnston, D. Staufen protein associates with the 3'UTR of bicoid mRNA to form particles that move in a microtubule-dependent manner. Cell 1994, 79, 1221-1232. [CrossRef]

346. Gardiol, A.; St Johnston, D. Staufen targets coracle mRNA to Drosophila neuromuscular junctions and regulates GluRIIA synaptic accumulation and bouton number. Dev. Biol. 2014, 392, 153-167. [CrossRef] [PubMed]

347. Roussis, I.M.; Guille, M.; Myers, F.A.; Scarlett, G.P. RNA Whole-Mount In situ Hybridisation Proximity Ligation Assay (rISH-PLA), an Assay for Detecting RNA-Protein Complexes in Intact Cells. PLoS ONE 2016, 11, e0147967. [CrossRef]

348. Gong, C.; Kim, Y.K.; Woeller, C.F.; Tang, Y.; Maquat, L.E. SMD and NMD are competitive pathways that contribute to myogenesis: Effects on PAX3 and myogenin mRNAs. Genes Dev. 2009, 23, 54-66. [CrossRef]

349. Broadus, J.; Fuerstenberg, S.; Doe, C.Q. Staufen-dependent localization of prospero mRNA contributes to neuroblast daughter-cell fate. Nature 1998, 391, 792-795. [CrossRef]

350. Li, P.; Yang, X.; Wasser, M.; Cai, Y.; Chia, W. Inscuteable and Staufen mediate asymmetric localization and segregation of prospero RNA during Drosophila neuroblast cell divisions. Cell 1997, 90, 437-447. [CrossRef]

351. Heber, S.; Gáspár, I.; Tants, J.-N.; Günther, J.; Moya, S.M.F.; Janowski, R.; Ephrussi, A.; Sattler, M.; Niessing, D. Staufen2-mediated RNA recognition and localization requires combinatorial action of multiple domains. Nat. Commun. 2019, 10, 1659. [CrossRef] [PubMed]

352. Lucas, B.A.; Lavi, E.; Shiue, L.; Cho, H.; Katzman, S.; Miyoshi, K.; Siomi, M.C.; Carmel, L.; Ares, M.; Maquat, L.E. Evidence for convergent evolution of SINE-directed Staufen-mediated mRNA decay. Proc. Natl. Acad. Sci. USA 2018, 115, 968-973. [CrossRef] [PubMed]

353. Sugimoto, Y.; Vigilante, A.; Darbo, E.; Zirra, A.; Militti, C.; D'Ambrogio, A.; Luscombe, N.M.; Ule, J. hiCLIP reveals the in vivo atlas of mRNA secondary structures recognized by Staufen 1 . Nature 2015, 519, 491-494. [CrossRef] [PubMed]

354. Kim, Y.K.; Furic, L.; Parisien, M.; Major, F.; DesGroseillers, L.; Maquat, L.E. Staufen1 regulates diverse classes of mammalian transcripts. EMBO J. 2007, 26, 2670-2681. [CrossRef] [PubMed]

355. Heraud-Farlow, J.E.; Sharangdhar, T.; Li, X.; Pfeifer, P.; Tauber, S.; Orozco, D.; Hörmann, A.; Thomas, S.; Bakosova, A.; Farlow, A.R.; et al. Staufen2 regulates neuronal target RNAs. Cell Rep. 2013, 5, 1511-1518. [CrossRef]

356. Laver, J.D.; Li, X.; Ancevicius, K.; Westwood, J.T.; Smibert, C.A.; Morris, Q.D.; Lipshitz, H.D. Genome-wide analysis of Staufen-associated mRNAs identifies secondary structures that confer target specificity. Nucleic Acids Res. 2013, 41, 9438-9460. [CrossRef]

357. LeGendre, J.B.; Campbell, Z.T.; Kroll-Conner, P.; Anderson, P.; Kimble, J.; Wickens, M. RNA targets and specificity of Staufen, a double-stranded RNA-binding protein in Caenorhabditis elegans. J. Biol. Chem. 2013, 288, 2532-2545. [CrossRef]

358. de Lucas, S.; Oliveros, J.C.; Chagoyen, M.; Ortín, J. Functional signature for the recognition of specific target mRNAs by human Staufen1 protein. Nucleic Acids Res. 2014, 42, 4516-4526. [CrossRef]

359. Furic, L.; Maher-Laporte, M.; DesGroseillers, L. A genome-wide approach identifies distinct but overlapping subsets of cellular mRNAs associated with Staufen1- and Staufen2-containing ribonucleoprotein complexes. RNA 2008, 14, 324-335. [CrossRef]

360. Sharangdhar, T.; Sugimoto, Y.; Heraud-Farlow, J.; Fernández-Moya, S.M.; Ehses, J.; Ruiz de Los Mozos, I.; Ule, J.; Kiebler, M.A. A retained intron in the 3'-UTR of Calm3 mRNA mediates its Staufen2- and activity-dependent localization to neuronal dendrites. EMBO Rep. 2017, 18, 1762-1774. [CrossRef] 
361. Duchaîne, T.F.; Hemraj, I.; Furic, L.; Deitinghoff, A.; Kiebler, M.A.; DesGroseillers, L. Staufen2 isoforms localize to the somatodendritic domain of neurons and interact with different organelles. J. Cell. Sci. 2002, 115, 3285-3295. [PubMed]

362. Sahoo, P.K.; Lee, S.J.; Jaiswal, P.B.; Alber, S.; Kar, A.N.; Miller-Randolph, S.; Taylor, E.E.; Smith, T.; Singh, B.; Ho, T.S.-Y.; et al. Axonal G3BP1 stress granule protein limits axonal mRNA translation and nerve regeneration. Nat. Commun. 2018, 9, 3358. [CrossRef] [PubMed]

363. Atlas, R.; Behar, L.; Elliott, E.; Ginzburg, I. The insulin-like growth factor mRNA binding-protein IMP-1 and the Ras-regulatory protein G3BP associate with tau mRNA and HuD protein in differentiated P19 neuronal cells. J. Neurochem. 2004, 89, 613-626. [CrossRef] [PubMed]

364. Ortega, A.D.; Willers, I.M.; Sala, S.; Cuezva, J.M. Human G3BP1 interacts with beta-F1-ATPase mRNA and inhibits its translation. J. Cell. Sci. 2010, 123, 2685-2696. [CrossRef] [PubMed]

365. Taniuchi, K.; Nishimori, I.; Hollingsworth, M.A. Intracellular CD24 inhibits cell invasion by posttranscriptional regulation of BART through interaction with G3BP. Cancer Res. 2011, 71, 895-905. [CrossRef]

366. Bikkavilli, R.K.; Malbon, C.C. Arginine methylation of G3BP1 in response to Wnt3a regulates $\beta$-catenin mRNA. J. Cell. Sci. 2011, 124, 2310-2320. [CrossRef]

367. Lypowy, J.; Chen, I.-Y.; Abdellatif, M. An alliance between Ras GTPase-activating protein, filamin C, and Ras GTPase-activating protein SH3 domain-binding protein regulates myocyte growth. J. Biol. Chem. 2005, 280, 25717-25728. [CrossRef]

368. Gallouzi, I.E.; Parker, F.; Chebli, K.; Maurier, F.; Labourier, E.; Barlat, I.; Capony, J.P.; Tocque, B.; Tazi, J. A novel phosphorylation-dependent RNase activity of GAP-SH3 binding protein: A potential link between signal transduction and RNA stability. Mol. Cell. Biol. 1998, 18, 3956-3965. [CrossRef]

369. Winslow, S.; Leandersson, K.; Larsson, C. Regulation of PMP22 mRNA by G3BP1 affects cell proliferation in breast cancer cells. Mol. Cancer 2013, 12, 156. [CrossRef]

370. Zekri, L.; Chebli, K.; Tourrière, H.; Nielsen, F.C.; Hansen, T.V.O.; Rami, A.; Tazi, J. Control of fetal growth and neonatal survival by the RasGAP-associated endoribonuclease G3BP. Mol. Cell. Biol. 2005, 25, 8703-8716. [CrossRef]

371. Taniuchi, K.; Nishimori, I.; Hollingsworth, M.A. The N-terminal domain of G3BP enhances cell motility and invasion by posttranscriptional regulation of BART. Mol. Cancer Res. 2011, 9, 856-866. [CrossRef] [PubMed]

372. Tourrière, H.; Gallouzi, I.E.; Chebli, K.; Capony, J.P.; Mouaikel, J.; van der Geer, P.; Tazi, J. RasGAP-associated endoribonuclease G3Bp: Selective RNA degradation and phosphorylation-dependent localization. Mol. Cell. Biol. 2001, 21, 7747-7760. [CrossRef] [PubMed]

373. Martin, S.; Tazi, J. Visualization of G3BP stress granules dynamics in live primary cells. J. Vis. Exp. 2014. [CrossRef] [PubMed]

374. Chen, Y.; Cohen, T.J. Aggregation of the nucleic acid-binding protein TDP-43 occurs via distinct routes that are coordinated with stress granule formation. J. Biol. Chem. 2019, 294, 3696-3706. [CrossRef]

375. Weber, S.C.; Brangwynne, C.P. Getting RNA and protein in phase. Cell 2012, 149, 1188-1191. [CrossRef]

376. Lin, Y.; Protter, D.S.W.; Rosen, M.K.; Parker, R. Formation and Maturation of Phase-Separated Liquid Droplets by RNA-Binding Proteins. Mol. Cell 2015, 60, 208-219. [CrossRef]

377. Shin, Y.; Brangwynne, C.P. Liquid phase condensation in cell physiology and disease. Science 2017, 357. [CrossRef]

378. Polymenidou, M. The RNA face of phase separation. Science 2018, 360, 859-860. [CrossRef]

379. Jain, S.; Wheeler, J.R.; Walters, R.W.; Agrawal, A.; Barsic, A.; Parker, R. ATPase-Modulated Stress Granules Contain a Diverse Proteome and Substructure. Cell 2016, 164, 487-498. [CrossRef]

380. Banani, S.F.; Lee, H.O.; Hyman, A.A.; Rosen, M.K. Biomolecular condensates: Organizers of cellular biochemistry. Nat. Rev. Mol. Cell Biol. 2017, 18, 285-298. [CrossRef]

381. Hofweber, M.; Dormann, D. Friend or foe-Post-translational modifications as regulators of phase separation and RNP granule dynamics. J. Biol. Chem. 2019, 294, 7137-7150. [CrossRef] [PubMed]

382. Miller, S.; Yasuda, M.; Coats, J.K.; Jones, Y.; Martone, M.E.; Mayford, M. Disruption of dendritic translation of CaMKIIalpha impairs stabilization of synaptic plasticity and memory consolidation. Neuron 2002, 36, 507-519. [CrossRef]

(C) 2020 by the authors. Licensee MDPI, Basel, Switzerland. This article is an open access article distributed under the terms and conditions of the Creative Commons Attribution (CC BY) license (http://creativecommons.org/licenses/by/4.0/). 